\title{
プラスチックボードドレーン打設機の 油圧抵抗を利用した地質推定手法の開発
}

\author{
平田 昌史 1 ・白神 新一郎 2 ・清水 英樹 3 ・福田 淳 4 ・川鍋 修 5 ・野村 忠明 6 \\ 1 正会員 前田建設工業株式会社＼cjkstart技術研究所（干179-8914 東京都練馬区旭町 1-39-16） \\ E-mail: hirata.m@jcity.maeda.co.jp \\ 2 正会員 錦城護謨株式会社 土木事業本部 技術部（ \\ E-mail: shinichirou.shiraga@kinjogomu.jp \\ 3 正会員＼cjkstart前田建設工業株式会社土木設計・技術部（†101-0064 東京都千代田区猿楽町 2-8-8） \\ E-mail: shimizuh@jcity.maeda.co.jp \\ 4 正会員＼cjkstart前田建設工業株式会社土木設計・技術部（广101-0064 東京都千代田区猿楽町 2-8-8） \\ E-mail: fukuda.jn@jcity.maeda.co.jp \\ 5 正会員 錦城護謨株式会社 土木事業本部（广581-0068 大阪府八尾市跡部北の町 1-4-25） \\ E-mail: shuu.kawanabe@kinjogomu.jp \\ 6 正会員 錦城護謨株式会社 土木事業本部（干581-0068 大阪府八尾市跡部北の町 1-4-25） \\ E-mail: tadaaki.nomura@kinjogomu.jp
}

\begin{abstract}
プラスチックボードドレーン（PBD）工法は，軟弱地盤内に PBD を多数打設することで圧密を促進させ る工法である。このため, 圧密対象層の層厚や分布位置が，改良効果に大きな影響を及ぼす。しかしなが ら，事前調査から地質分布を推定することには限界があるため，期待した改良効果が得られない場合も多 い. 本論文では，PBD 打設機の油圧抵抗から，静的コーン貫入試験における貫入抵抗を算定する推定式を 提案し，地盤強度の定量的な評価を行った。また，PBD 打設地盤の強度分布や地質分布を連続的かつ多次 元的に評価するシステムを作成し，その有効性を検討した。本システムから推定した強度分布や地質分布 は, 実際の地盤を精度良く表現できており, 沈下・安定計算や FEM 変形解析等へ利用することで, 工期短 縮や工程管理に有用であると考えられる.
\end{abstract}

Key Words : plastic board drain, oil pressure resistance, cone penetration test

\section{1. はじめに}

軟弱地盤対策工法の 1 つであるバーチカルドレー ン工法は，軟弱地盤内の鉛直方向に排水柱を多数設 置し，水平方向の排水距離を短縮することによって 圧密を促進させ，地盤の強度増加や残留沈下抑制を 期待する工法である.バーチカルドレーン工法では, 圧密対象となる軟弱層（粘性土）の層厚や分布位置 が改良効果に大きな影響を及ぼすため，事前調査に よって地質分布を把握し, 適切なドレーン配置や圧 密放置期間を設定することが重要となる.しかしな がら, 堆積環境が複雑な地盤では, わずか数箇所の 事前調査結果から地質分布を推定することには限界 があるため，期待した改良効果が得られない場合が
あり，ドレーンによる圧密促進効果自体に疑問を抱 く声もある.このような問題を解決するためには, バーチカルドレーンが施工された地盤の地質分布を 詳細に把握するとともに，実際の地質分布に沿った 圧密沈下予測を適宜実施し, 設定したドレーン配置 や圧密放置期間が適切であるかを管理・判断するこ とが求められる.

本論文で取り上げるプラスチックボードドレーン （以下，PBD）工法は，鉛直排水柱に PBD を用いる 工法であり，鉛直排水柱に砂を用いるサンドドレー ン工法に比べて, 材質が一定で供給が安定しており, 施工能率が良く経済的であるため，近年需要が伸び ている工法である. PBD 工法の一般的な施工管理で は，オシログラフに記録されたケーシングの貫入深 


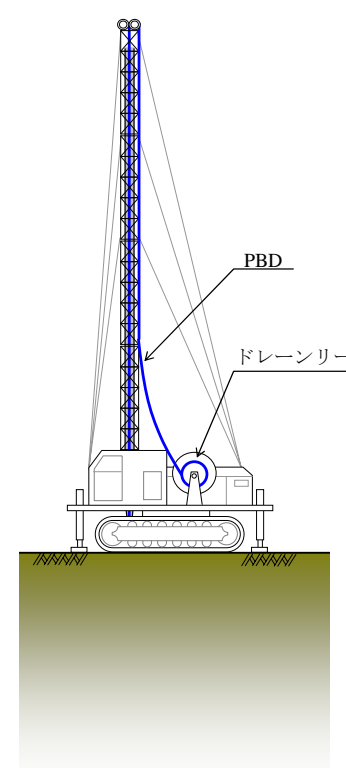
(1) PBD を櫓上部からケーシング
内にセット

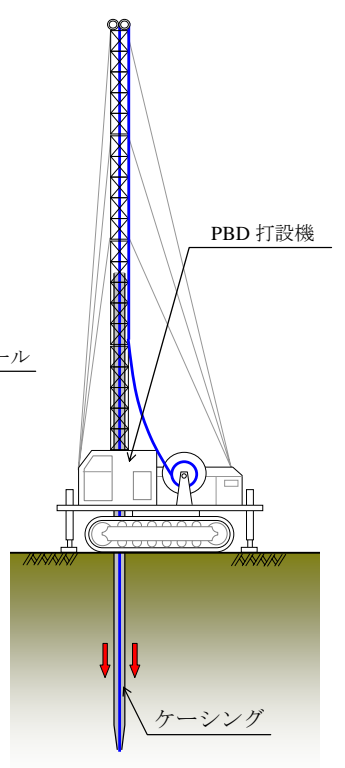

（2）ケーシングを地盤内に貫入

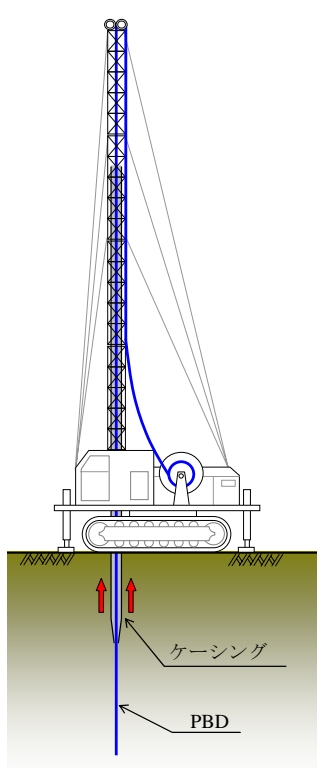

(3) PBDを地盤内に残し, ケーシ ングのみ引拔き

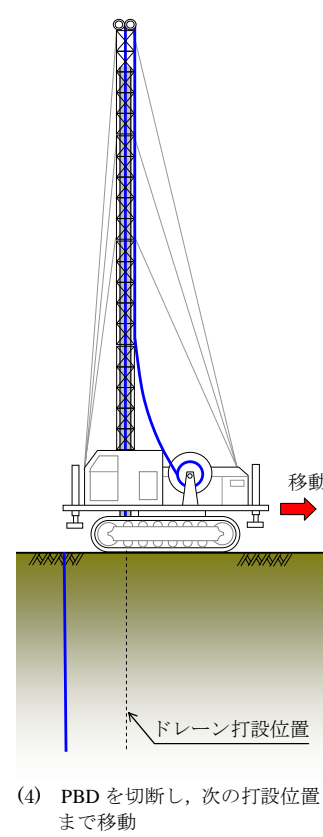

まで移動

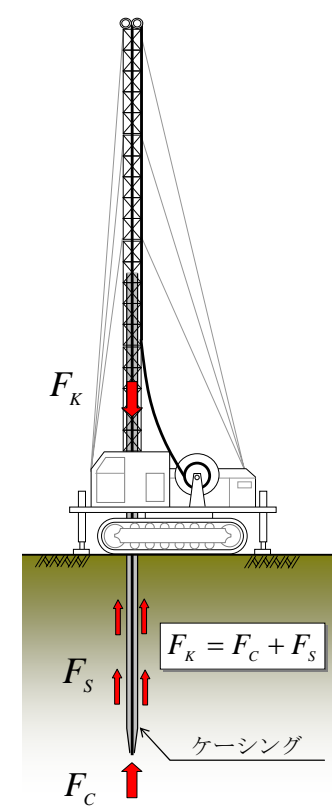

図-2 力の釣合い

図-1プラスチックボードドレーン

（PBD）工法の施工手順 ${ }^{1)}$

がみられ，油圧抵抗を用いて地盤強度を評価する検 討 2), 3) も実施されており，オシログラフに記録され た油圧抵抗が，軟弱地盤内に介在する硬い層（砂層） の判別に有効であることが示されている。しかしな がら，これらの検討事例では，油圧抵抗に対して相 対的な評価を行うため, 得られる結果は対象地盤の 土質性状に依存し, 力学的意味も曖昧である.

そこで，静的コーン貫入試験や杭の極限支持力の メカニズムを参考に，オシログラフに記録された油 圧抵抗から, 静的コーン貫入試験の貫入抵抗を推定 する簡便式の導出を試みる，図-2に示すように，ケ ーシング貫入時の力の釣合い式を，

$$
F_{K}=F_{C}+F_{S}
$$

内の地盤強度分布や地質分布を連続的かつ多次元的 に評価するシステムを作成し，その適用性・有用性 に関する検討も行った。

\section{PBD 打設時の貫入力推定式の誘導}

\section{(1) PBD の施エとカの釣合い式}

PBD 工法は, 図-1 に示寸ようにケーシング内にド レーン材（プラスチックボード）をセットし，この ケーシングを地盤に貫入することで, 軟弱地盤内に ドレーン材を押込む工法である.このような PBD 工 法の施工は，静的コーン貫入試験におけるロッドの 貫入や，小口径の杭を地盤に打設することに酷似し ている.このため, ケーシング貫入時の油圧抵抗と 静的コーン貫入試験の貫入抵抗の間には良い相関性

と定義する． $F_{K}$ はケーシングの貫入力， $F_{C}$ はケー シングの先端抵抗力, $F_{S}$ はケーシングに作用する周 面摩擦抵抗力である.この力の釣合い式を，静的コ ーン貫入試験の貫入抵抗で表すことができれば，地 盤強度の定量的な評価が可能となる。

\section{（2）ケーシングに作用する先端抵抗力}

ケーシングに作用する先端抵抗力 $F_{C}$ は, ケーシン グ先端の貫入抵抗 $\hat{q}_{C}$ とケーシングの断面積 $A_{K}$ より, 次のように表される.

$$
F_{C}=A_{K} \cdot \hat{q}_{C}
$$

ここで，PBD 打設時におけるケーシングの貫入が， 大型の静的コーン貫入試験を実施することと等価で あると捉えるならば, ケーシング先端の貫入抵抗 $\hat{q}_{C}$ 
は, 静的コーン貫入試験における貫入抵抗 $q_{C}$ と等価 であると考えることができる. 但し, 静的コーン貫 入試験におけるロッド貫入速度が通常 0.01 $0.02 \mathrm{~m} / \mathrm{s}$ 程度であるのに対して, PBD 打設時のケー シング貫入速度は約 $0.3 \sim 0.5 \mathrm{~m} / \mathrm{s}$ と非常に速いため, 貫入速度の影響を考慮する必要がある。また，図-3 に示寸ように，今回使用したケーシングの先端形状 と静的コーン貫入試験のコーン先端形状が異なるこ とから，このような先端形状の影響も考慮しなけれ ばならない。ここでは, 貫入速度やコーン先端形状 の影響 4 ), 5)を, 補正係数 $\alpha$ を用いて考慮し,

$$
\hat{q}_{C}=\alpha \cdot q_{C}
$$

と定義する. 式(3)を式(2)に代入すると，ケーシング に作用する先端抵抗力 $F_{C}$ は, 静的コーン貫入試験に おける貫入抵抗 $q_{C}$ を用いて,

$$
F_{C}=\alpha \cdot A_{K} \cdot q_{C}
$$

と表される.

\section{(3) ケーシングに作用する周面摩擦抵抗力}

次に, ケーシングに作用する周面摩擦抵抗力 $F_{S}$ に ついて考えてみる. 静的コーン貫入試験の場合, 口 ッドに作用する周面摩擦抵抗力には, ある一定の深 度以降は増加しない臨界深さがあるとされ, 例えば 均質な軟弱粘土では, ロッドを 5 6m 程度貫入する と周面摩擦抵抗力はほぼ一定となってしまうとの報 告 ${ }^{7)}$ ある。これは, ロッドが一般的に曲がりやす いため, ロッドの貫入が進むにつれて貫入孔が拡大 し，ロッドと孔壁に隙間が生じて摩擦が発揮されな いことが要因の 1 つとして挙げられる。これに対し て, PBD 打設機のケーシングは, 静的コーン貫入試 験のロッドに比べて曲がり難く,断面積も20 倍程度

（図-3 参照）あることから，孔壁との隙間の影響は ほとんど生じないものと考えられる。ここでは, 杭 の極限支持力の考え方と同様に，ケーシングに作用 寸る周面摩擦抵抗力 $F_{s}$ が, 地表から先端位置までの 局部周面摩擦 $\hat{f}_{s}$ の累積であるとして,

$$
F_{S}=\int_{0}^{z} \hat{f}_{s} \cdot D_{K} \cdot d z
$$

と表す． $D_{K}$ はケーシングの周長， $\mathrm{z}$ はケーシングの 打設深度である. ケーシングに作用する局部周面摩 擦 $\hat{f}_{s}$ については, 前述した貫入抵抗と同様に, 静的 コーン貫入試験（電気式コーン試験等）で計測され る局部周面摩擦 $f_{s}$ と相関があるものとする. 但し, 静的コーン貫入試験で使用するフリクションスリー ブと PBD 打設機のケーシングの材質の違い, 動摩擦 の影響, ケーシング周辺地盤のリモールドの影響等

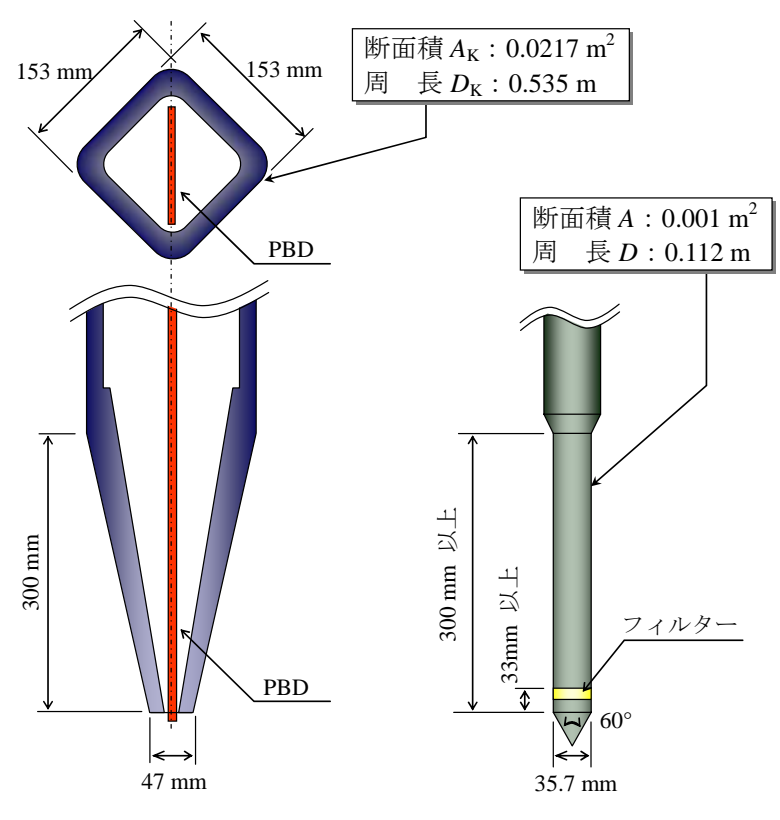

(a) ケーシング先端形状

(b) コーン先端形状

図-3 ケーシングの先端形状と電気式コーン先端形状 (地盤工学会基淮 ${ }^{6}$ ) の比較

を, 補正係数 $\beta$ を用いて考慮し，

$$
\hat{f}_{s}=\beta \cdot f_{s}
$$

と定義する.この式(6)を式(5)に代入することで, 周 面摩擦抵抗力 $F_{S}$ は,

$$
F_{S}=\beta \cdot D_{K} \int_{0}^{z} f_{S} d z
$$

と表される。 なお, 補正係数 $\beta$ については, 深度方 向に一様に作用寸るものと仮定している.

静的コーン貫入試験による局部周面摩擦 $f_{s}$ につ いては, 貫入抵抗 $q_{C}$ と相関性があることが知られて いる．この相関性を利用することで，静的コーン貫 入試験結果から土質を判定することが可能である.

Begemann $^{8)}$ は局部周面摩擦 $f_{s}$ と貫入抵抗 $q_{C}$ を用い た土質判別チャートを, Schmertmann ${ }^{9}$ は周面摩擦係 数 $F R\left(=f_{s} / q_{c}\right)$ を用いた土質判別チャートを提案 している. また, Robertson ${ }^{10)}$ は電気式コーン貫入試 験から得られる間隙水圧も考慮した土質判別チャー 卜を提案している. PBD を施工寸る場合, 電気式コ ーン貫入試験のように間隙水圧は計測できないため, ここでは周面摩擦係数 $F R$ を用いて局部周面摩擦 $f_{s}$ を評価する. PBD が施工される地盤は, 圧密促進を 必要とする軟弱地盤であり, 対象となる土質は透水 性が低い軟弱な粘性土・腐植土である. Begemann や Schmertmann の土質判別チャートによると, 軟弱 な粘性土の周面摩擦係数 $F R$ は概衫 $0.03 \sim 0.07$ の值 であるが，ここでは式を簡略化するために，周面摩 擦係数 $F R$ を 0.05 の一定值と仮定して, 


$$
\begin{aligned}
F_{S} & =\beta \cdot D_{K} \int_{0}^{z} F R \cdot q_{C} d z \\
& =0.05 \cdot \beta \cdot D_{K} \int_{0}^{z} q_{C} d z
\end{aligned}
$$

とする.また，ケーシング周面の貫入抵抗 $q_{C}$ の平均 值を $\bar{q}_{C}$ と置くと，

$$
\int_{0}^{z} q_{C} d z=\frac{\int_{0}^{z} q_{C} d z}{z} \cdot z=\bar{q}_{C} \cdot z
$$

であり, 式(8)に示した周面摩擦抵抗力 $F_{S}$ は, この平 均貫入抵抗 $\bar{q}_{C}$ を用いて,

$$
F_{S}=0.05 \cdot \beta \cdot \bar{q}_{C} \cdot A_{K S}
$$

と表される. なお, $A_{K S}\left(=D_{K} \cdot z\right)$ は地盤内に貫入 したケーシングの周面積である.

\section{(4) ケーシングの貫入力推定式}

ケーシングの貫入力算定式は，式(1)に示したケー シングに作用する力の釣合式に，式(4)および式(10) を代入することにより，

$$
F_{K}=\alpha \cdot A_{K} \cdot q_{C}+0.05 \cdot \beta \cdot \bar{q}_{C} \cdot A_{K S}
$$

と求められる. この貫入力算定式は, 貫入抵抗 $q_{C}$ の みからケーシングの貫入力 $F_{K}$ を算定できる簡便な 式となっている。一方, Meyerhoff ${ }^{11)}$ は砂地盤を対象

$（ F R=0.005 ）$ として，杭の極限支持力算定式を次 のように定義している。

$$
Q=A \cdot q_{C}+0.005 \cdot \bar{q}_{C} \cdot A_{S}
$$

$Q$ は杭の極限支持力, $A$ は杭の底面積, $A_{s}$ は地盤 内に打設した杭の周面積である. 式(11)と式(12)を比 較すると，両者は同じ形式であることがわかる。つ まり，式(11)で誘導したケーシングの貫入力算定式 は，Meyerhoff による杭の極限支持力算定式に対し て，貫入速度や先端形状，摩擦係数の違いや地盤の リモールド等のさまざまな影響を補正係数 $\alpha, \beta$ を 用いて考慮し，拡張した式であるといえる.

\section{3. ケーシング貫入力と油圧抵抗の関係}

\section{(1) ケーシング貫入力と油圧抵抗の関係式の誘導}

写真-1 は，フリクションローラ式 PBD 打設機の ケーシング付近の写真である. 図-4 に示寸模式図の ように，油圧モータに油圧が作用することで，油圧 モータが回転しトルク力を発揮し, ギアを通してフ リクションローラにカが伝達され，ケーシングを押 込む機構となっている. オシログラフに記録される

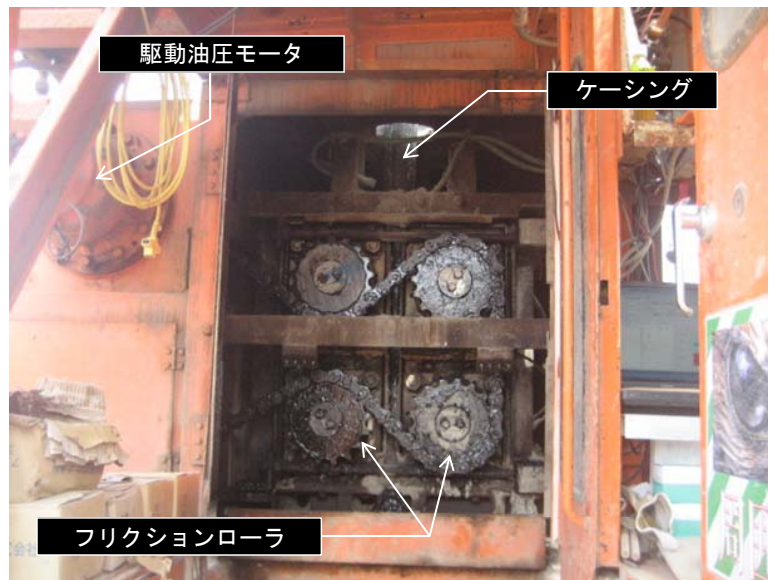

写真-1ケーシングとフリクションローラ

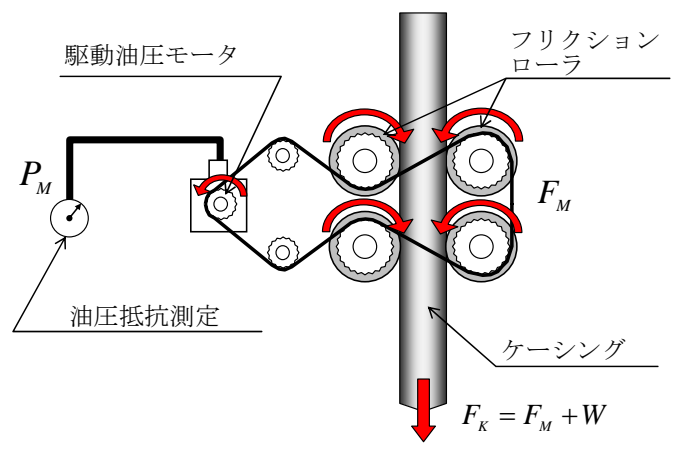

図-4ケーシング貫入機構の模式図

油圧抵抗 $P_{M}$ は，PBD 打設機の油圧モータに作用す る油圧を測定したものであり，ケーシングの貫入力 $F_{K}$ を測定したものではない。このため, 式(11)に示 した貫入力推定式を使用するためには，オシログラ フに記録される油圧抵抗 $P_{M}$ と, ケーシングの貫入力 $F_{K}$ の関係を明らかにすることが必要である.

ケーシングの貫入力 $F_{K}$ は，図-4 に示すようにそ の機構上，油圧モータによる押込み力 $F_{M}$ と，ケー シングの重量 $W$ との足し合わせとなる.

$$
F_{K}=F_{M}+W
$$

なお，ケーシングに作用する浮力は，式(11)右辺に 抵抗力として既に含まれているため，式(13)に示す ケーシングの貫入力 $F_{K}$ に考慮する必要はない. 油圧 モータによる押込み力 $F_{M}$ は，油圧モータが発揮す るトルクや PBD 打設機の伝達効率等の影響によっ て決まるものであるため, 油圧抵抗 $P_{M}$ との間に比例 関係が成り立つものと仮定し，変換係数 $\mu$ を用いて，

$$
F_{M}=\mu \cdot P_{M}
$$

と置く.ケーシングの貫入力 $F_{K}$ と油圧抵抗 $P_{M}$ の関 係式は，式(13)に式(14)を代入することで，

$$
F_{K}=\mu \cdot P_{M}+W
$$

と求められる。 


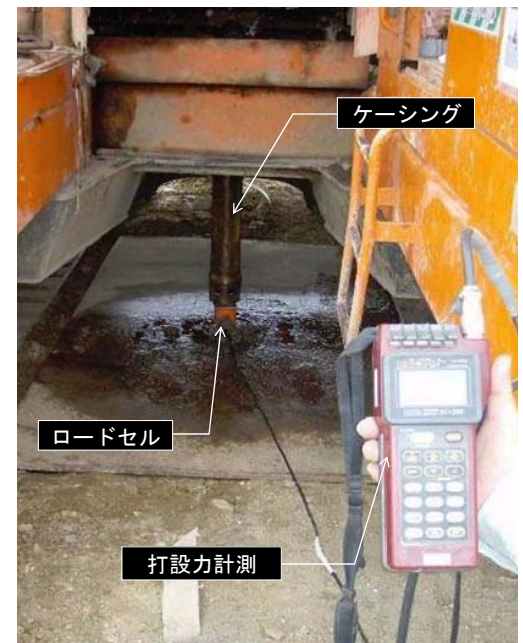

写真-2 検定試験状況

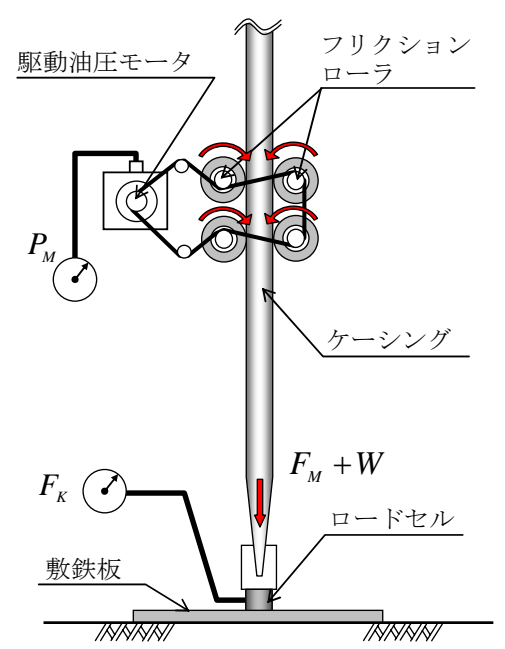

図-5 打設力検定試験の模式図
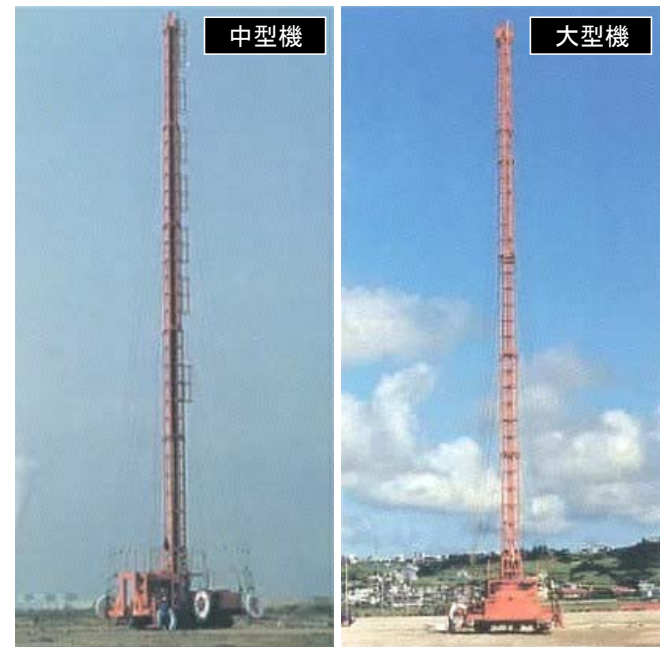

写真-3 PBD 打設機

\section{(2) PBD 打設機を用いた打設力検定試験}

油圧抵抗 $P_{M}$ からケーシングの貫入力 $F_{K}$ を求める ためには, 式(15)に示した変換係数 $\mu$ が必要である. ここでは, 実際の PBD 打設機を用いた打設力検定試 験を実施し, 変換係数 $\mu$ の推定を試みた. 写真-2 は, 打設力検定試験の実施状況である. 打設力検定試験 では，図-5に示すように敷鉄板の上にロードセルを 設置し, ケーシングを押込む際の油圧抵抗 $P_{M}$ を計測 すると同時に，ケーシング先端に設置したロードセ ルを用いて貫入力 $F_{K}$ を直接測定する. なお，ケーシ ング先端とロードセルの間には, 鉛直に荷重が伝達 されるように治具を配置している，表-1 は，実施し た打設力検定試験の一覧である. なお，表-1 に示し たケーシング重量は, PBD 打設機にセットしたケー シング長から算定している，検定試験では，写真-3 に示した中型機（PDC-200 型）と大型機（PDC-300 型）の 2 種類の PBD 打設機を使用した.

図-6 は，中型機（PDC-200 型）を使用した場合の 試験結果である. 横軸は油圧抵抗 $P_{M}$, 縦軸はケーシ ングの貫入力 $F_{K}$ から重量 $W$ を引いて算定した油圧 モータよる押込み力 $F_{M}\left(=F_{K}-W\right)$ である。この 結果, 油圧抵抗 $P_{M}$ と油圧モー夕による押込み力 $F_{M}$ の間には，ほぼ比例関係が成り立つことがわかる.

また，この結果より式(15)に示した変換係数は $\mu=0.0032$ と求めることができる.

図-7 は，大型機（PDC-300 型）を使用した場合の 試験結果である. 図中には, 同型の PBD 打設機の試 験結果をすべてプロットしている. 油圧抵抗 $P_{M}$ と油 圧モータの押込み力 $F_{M}$ の間には, 中型機と同様に ほぼ比例関係が成り立ち, 式(15)に示した変換係数 を $\mu=0.0050$ と求めることができる. なお，若干の 誤差はあるが, 同型の PBD 打設機であれば各機体に よる差はほとんどないこともわかる。
表-1 実施した打設力検定試験一覧

\begin{tabular}{|c|c|c|c|c|}
\hline \multirow{2}{*}{ 試験番号 } & \multicolumn{3}{|c|}{ PBD打設機 } & ケーシング重量 \\
\hline & 機体番号 & & & $\begin{array}{ll}W & (\mathrm{MN}) \\
\end{array}$ \\
\hline $\mathrm{D}-01$ & 202号機 & PDC-200 & 中型機 & 0.0157 \\
\hline $\mathrm{D}-02$ & 302号機 & \multirow{5}{*}{ PDC-300 } & \multirow{5}{*}{ 大型機 } & 0.0098 \\
\hline $\mathrm{D}-03$ & 314号機 & & & 0.0098 \\
\hline D-04 & 302号機 & & & 0.0176 \\
\hline D-05 & 312号機 & & & 0.0176 \\
\hline $\mathrm{D}-06$ & 310 号機 & & & 0.0078 \\
\hline
\end{tabular}

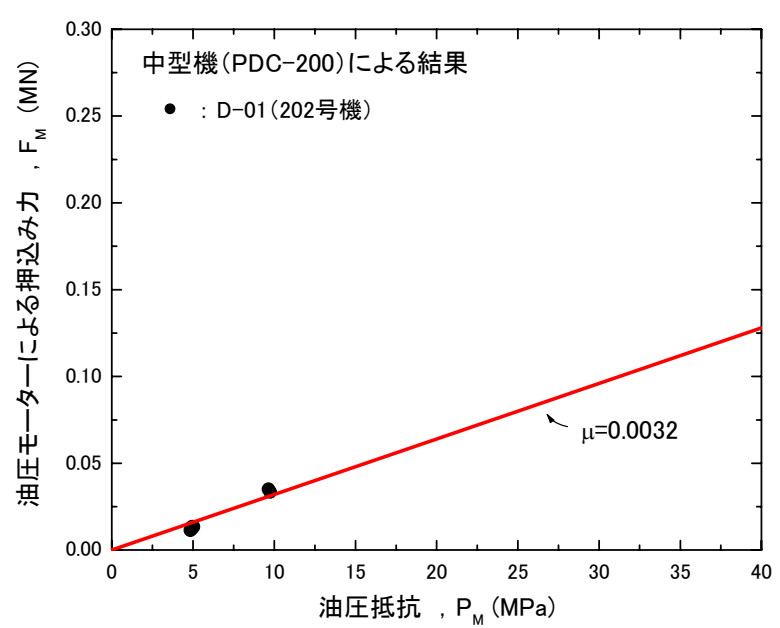

図-6 中型機による打設力検定試験結果

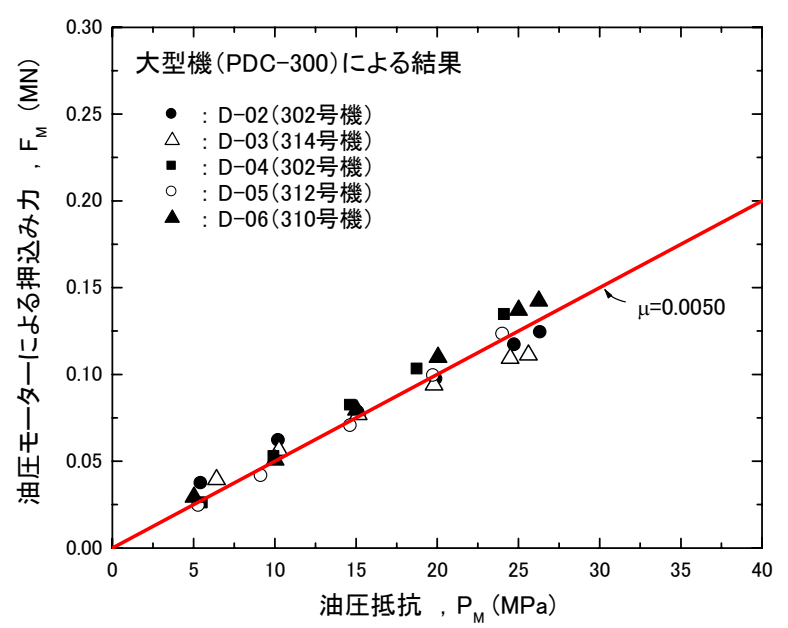

図-7 大型機による打設力検定試験結果 
以上のことから, 現場で使用した PBD 打設機の仕 様 (型番, ケーシング長) がわかれば, 変換係数 $\mu$ とケーシングの重量 $W$ を定めることができ, 油圧抵 抗 $P_{M}$ から式(15)を用いてケーシングの貫入力 $F_{K}$ を 算定することが可能である.

\section{4. 貫入力推定式における補正係数の決定}

\section{(1) ケーシングの押込み・引抜き試験}

静的コーン試験の貫入抵抗 $q_{C}$ をオシログラフの 油圧抵抗 $P_{M}$ から推定する場合, 式(11)に示した補正 係数 $\alpha, \beta$ の值が必要となる. この補正係数 $\alpha, \beta$ には, 貫入速度や先端形状, 摩擦係数の違いや地盤 のリモールド等, さまざまな影響が考慮されている ため, 理論的あるいは解析的に值を定めることは困 難である.また, 実際の PBD 打設時の油圧抵抗から 補正係数を求めようとしても, 式(11)に未知数が 2 つ含まれるため, 補正係数を一意に定めることがで きない.そこで，ケーシングの押込み・引抜き試験 結果を基に, 補正係数 $\alpha, \beta$ の值の検討を試みた. 図-8 は, ケーシング押込み時・引抜き時における力 の釣合いを示した模式図である，ケーシングを押込 む際の力 $\left.F_{K}\right|_{\text {押 }}$ 式(1)より,

$$
\left.F_{K}\right|_{\text {押 }}=F_{C}+F_{S}
$$

である.これに対して，ケーシングを引抜く際の力 $\left.F_{K}\right|_{\text {引l }}$ には先端抵抗力 $F_{C}$ が作用しないため,

$$
\left.F_{K}\right|_{引 1}=F_{S}
$$

となる. 式(16)および式(17)に示したケーシングの押 込み力と引抜き力の差を取ると，

$$
\left.F_{K}\right|_{\text {押 }}-\left.F_{K}\right|_{\text {引1 }}=F_{C}
$$

と表される．このように，ケーシングの押込み・引 抜き試験を実施することで，ケーシングに作用する 先端抵抗力 $F_{C}$ と周面摩擦抵抗力 $F_{S}$ を個別に求める ことができ, 補正係数 $\alpha, \beta$ の值を検討することが 可能になる.

表-2 は，実施したケーシングの押込み・引抜き試 験の一覧である. 試験ヤード内の 2 箇所で実施した 静的コーン貫入試験の周囲 12 箇所で, ケーシングの 貫入速度を変えた押込み・引抜き試験を実施してい る. なお，使用した PBD 打設機は中型機（PDC-200） であり, ケーシングの重量 $W$ は 0.0157MN である.

図-9 は, 静的コーン貫入試験による貫入抵抗 $q_{C}$ の 深度分布である. 試験ヤードの地盤は, 比較的硬い 層（砂層）が地表から G.L.-4m 付近にかけて分布し
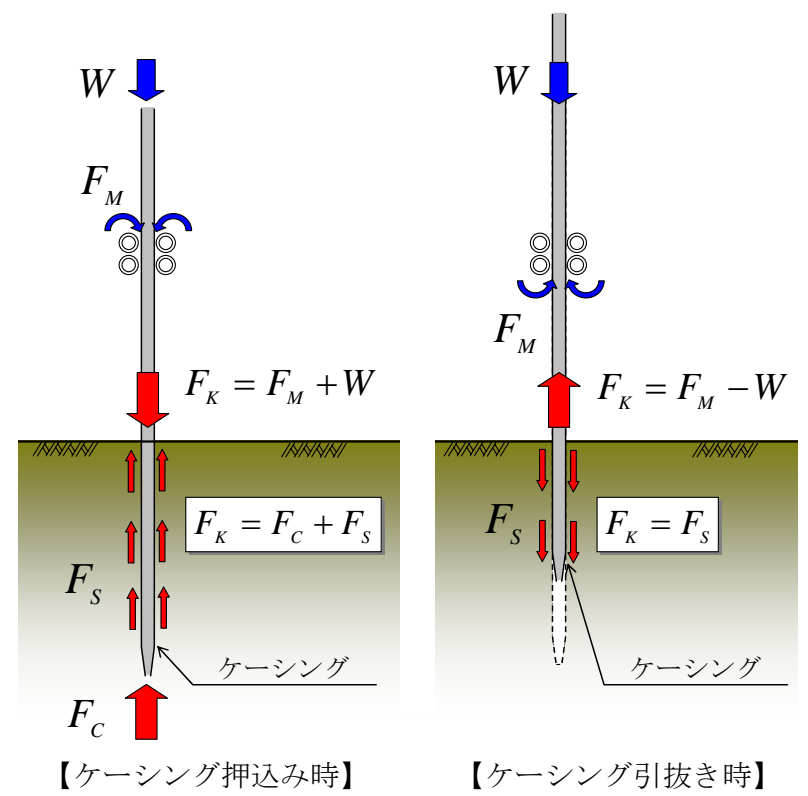

【ケーシング押込み時】

\begin{tabular}{|c|c|c|c|c|c|c|c|}
\hline \multirow{2}{*}{$\begin{array}{l}\text { 静的コーン } \\
\text { 貫入試験 No. }\end{array}$} & \multirow{2}{*}{$\begin{array}{l}\text { 打設試験 } \\
\text { No. }\end{array}$} & \multicolumn{2}{|c|}{ 貫入速度 $V[\mathrm{~m} / \mathrm{s}]$} & \multirow{2}{*}{$\begin{array}{l}\text { 静的コーン゙ } \\
\text { 貫入試験 No. }\end{array}$} & \multirow{2}{*}{$\begin{array}{l}\text { 打設試験 } \\
\text { No. }\end{array}$} & \multicolumn{2}{|c|}{ 貫入速度 $V[\mathrm{~m} / \mathrm{s}]$} \\
\hline & & 押込及時 & 引抜き時 & & & 押込从時 & 引抜き時 \\
\hline \multirow{12}{*}{ СРТ-01 } & T1-A-01 & 1.0 & 0.8 & \multirow{12}{*}{ СРТ-02 } & T2-A-01 & 1.0 & 1.0 \\
\hline & T1-A-02 & 1.0 & 0.8 & & T2-A-02 & 1.0 & 1.0 \\
\hline & T1-A-03 & 1.0 & 0.8 & & T2-A-03 & 1.0 & 1.0 \\
\hline & T1-B-01 & 0.5 & 0.5 & & T2-B-01 & 0.9 & 0.9 \\
\hline & T1-B-02 & 0.5 & 0.5 & & T2-B-02 & 0.9 & 0.9 \\
\hline & T1-B-03 & 0.5 & 0.5 & & T2-B-03 & 0.9 & 0.9 \\
\hline & T1-C-01 & 0.3 & 0.4 & & T2-C-01 & 0.6 & 0.6 \\
\hline & T1-C-02 & 0.3 & 0.4 & & T2-C-02 & 0.6 & 0.6 \\
\hline & T1-C-03 & 0.3 & 0.4 & & T2-C-03 & 0.6 & 0.6 \\
\hline & T1-D-01 & 0.2 & 0.3 & & T2-D-01 & 0.8 & 0.8 \\
\hline & T1-D-02 & 0.2 & 0.3 & & T2-D-02 & 0.8 & 0.8 \\
\hline & \begin{tabular}{|l|} 
T1-D-03 \\
\end{tabular} & 0.2 & 0.3 & & \begin{tabular}{|l|} 
T2-D-03 \\
\end{tabular} & 0.8 & 0.8 \\
\hline
\end{tabular}

図-8 ケーシング押込み・引抜き時の力の釣合い

表-2 実施した押込み・引抜き試験の一覧

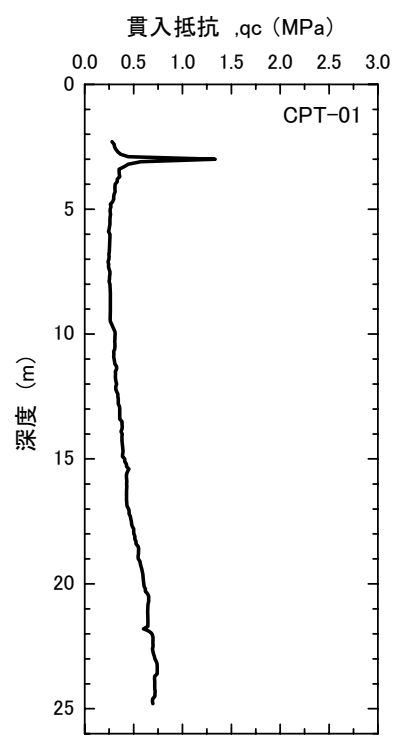

貫入抵抗, qc (MPa)

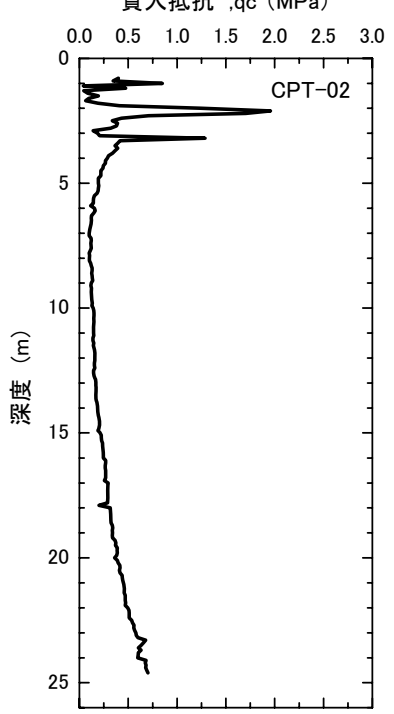

図-9 静的コーン貫入試験結果

ており，その下に軟弱層（粘性土）が厚く堆積して いる．図-10 は，押込み・引抜き試験において測定 した油圧抵抗 $P_{M}$ の深度分布である. 式(11)に示した 推定式は, 圧密促進を必要とする軟弱層（粘性土） を対象としているため，ここでは G.L.-5m 付近に分 布する硬い層（砂層）の油圧抵抗データは割愛して 


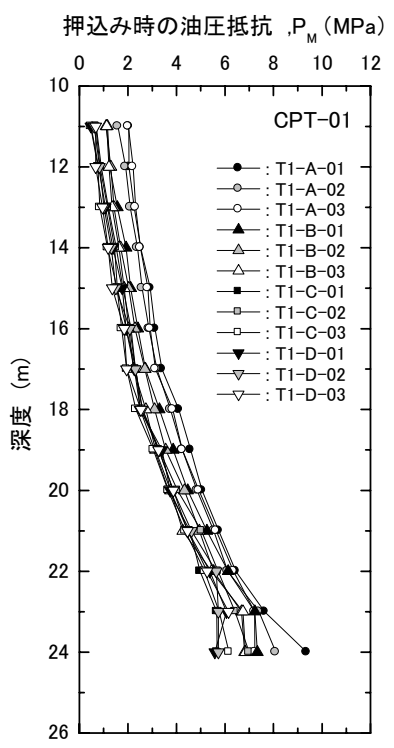

(a) CPT-01 位置における試験結果
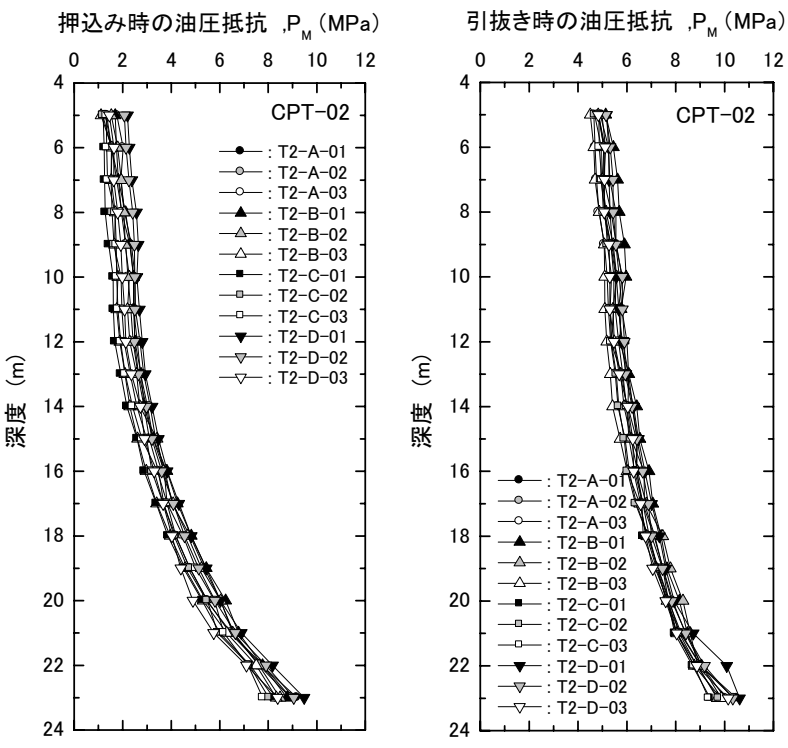

(b) CPT-02 位置における試験結果

図-10 ケーシングの押込み・引抜き試験による油圧抵抗深度分布

いる. なお，油圧抵抗 $P_{M}$ には $1.0 \sim 1.5 \mathrm{MPa}$ 程度の範 囲でズレが見られる。これは，G.L.-5m 付近に分布 する硬い層（砂層）の層厚が異なる影響であり，深 度方向に対する油圧抵抗の増分量には，ほとんど差 が見られない。

\section{(2) 先端抵抗力に作用する補正係数 $\alpha$ の検討}

ケーシング押込み時の力 $\left.F_{K}\right|_{\text {押 }}$, 押込み時の油圧

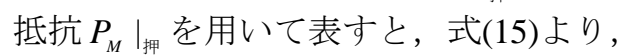

$$
\left.F_{K}\right|_{\text {押 }}=\left.\mu \cdot P_{M}\right|_{\text {押 }}+W
$$

である。一方，ケーシング引抜き時の力 $\left.F_{K}\right|_{\mid{ }_{\mid}}$には， ケーシングの自重 $W$ が押込み時とは逆に作用寸る ため, 引抜き時の油圧抵抗 $\left.P_{M}\right|_{\text {引 }}$ を用いて,

$$
\left.F_{K}\right|_{\xi 1}=\left.\mu \cdot P_{M}\right|_{\xi 1}-W
$$

と表される. 式(19)と式(20)を式(18)に代入すると，

$$
F_{C}=\mu \cdot\left(\left.P_{M}\right|_{\text {押 }}-\left.P_{M}\right|_{\zeta \mid}\right)+2 W
$$

となり，ケーシングの先端抵抗力 $F_{C}$ を油圧抵抗 $P_{M}$ から求めることができる。 また，ケーシングの先端 抵抗力 $F_{C}$ と静的コーン貫入試験の貫入抵抗 $q_{C}$ の間 には, 式(4)のように比例関係が成り立つと仮定して おり,

$$
F_{C}=\alpha \cdot A_{K} \cdot q_{C} \quad(4) \text { : 再掲 }
$$

である．この式(4)と式(21)を比較することで, 補正 係数 $\alpha$ の検討を行った.

図-11 は, 縦軸を油圧抵抗 $P_{M}$ から算定したケーシ ングの先端抵抗力 $F_{C}$, 横軸を貫入抵抗 $q_{C}$ から求め たケーシングの先端抵抗力 $\left(q_{C} \times A_{K}\right)$ として, 試験

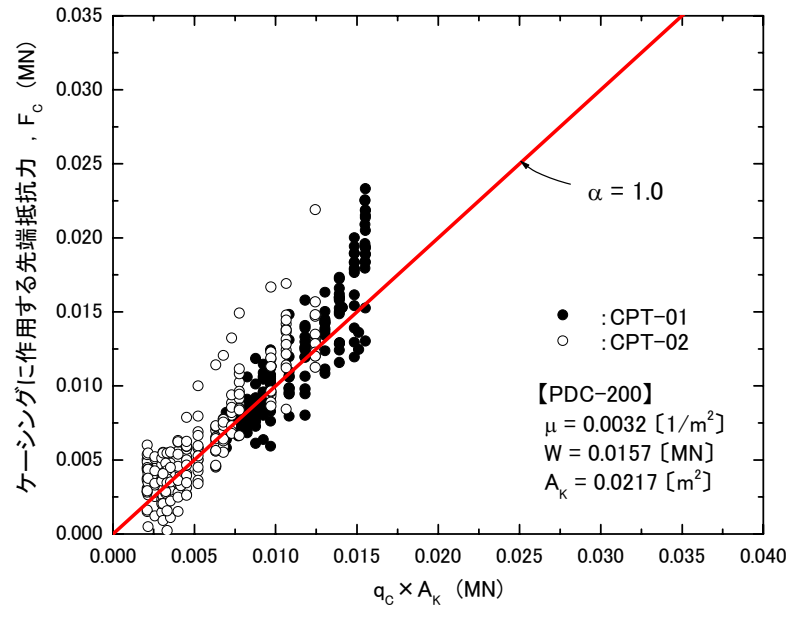

図-11 補正係数 $\alpha$ の検討結果

結果を整理した図である，図中には，実施した試験 ケースのす心゙てをプロットしている．若干バラッキ は見られるが，両者の間にはほぼ比例関係が成り立 つと考えられ, 補正係数 $\alpha$ は 1.0 と求められる. な お，補正係数 $\alpha$ にはケーシング貫入速度の影響も考 慮されているが，今回試験を実施した貫入速度 0.2 $\sim 1.0 \mathrm{~m} / \mathrm{s}$ の間では, 補正係数 $\alpha$ の值に明確な差は生 じておらず, 通常の PBD 施工範囲内では, 貫入速度 の影響を考慮する必要はないと考えられる.

\section{(3) 周面摩擦抵抗力に作用する補正係数 $\beta$ の検討}

ケーシングの周面摩擦抵抗力 $F_{S}$ は, 式(17)に式 (20)を代入することで，引抜き時の油圧抵抗 $\left.P_{M}\right|_{\text {引 }}$ を 用いて次のよう表される.

$$
F_{S}=\left.\mu \cdot P_{M}\right|_{31}-W
$$

また, ケーシングの周面摩擦抵抗力 $F_{S}$ と静的コーン 
貫入試験の貫入抵抗 $q_{C}$ の間には, 式(10)に示す関係 が成り立つと仮定しており，

$$
F_{S}=0.05 \cdot \beta \cdot \bar{q}_{C} \cdot A_{K S} \quad(10): \text { 再掲 }
$$

である.この式(10)と式(22)を比較することで, 補正 係数 $\beta$ の検討を行った.

図-12 は, 縦軸を油圧抵抗 $P_{M}$ から算定したケーシ ングの周面摩擦抵抗力 $F_{S}$, 横軸を静的コーン貫入試 験の貫入抵抗 $q_{C}$ の平均値から算定した周面摩擦抵 抗力 $\left(0.05 \times \bar{q}_{C} \times A_{K S}\right)$ として, 試験結果を整理した 図である，若干バラツキはあるもの，両者の間には ほぼ比例関係が成り立つといえる.また補正係数 $\beta$ は, ケーシングと地盤の摩擦係数の影響, 周辺地盤 のリモールドの影響を考慮した值であり，対象地盤 の地質の違いによって影響を受けるものと考えられ るが, 今回のケースでは補正係数 $\beta$ は 0.06 と求める ことができる. なお, 補正係数 $\beta$ は理論上ケーシン グ貫入速度の影響は受けない. 図中には, 実施した 試験ケースの寸心゙てをプロットしているが，貫入速 度の違いによる差はほとんど生じていないことも確 認できる.

\section{（4）貫入力推定式を用いた貫入抵抗の算定}

式(11)に示寸貫入力推定式を用いて, 図-10に示し た押込み時の油圧抵抗 $\left.P_{M}\right|_{\text {押 }}$ から, 静的コーン貫入試 験による貫入抵抗 $q_{C}$ の算定を試みた. 補正係数には, $\alpha=1.0, \quad \beta=0.06$ を用いている.

図-13 は, 油圧抵抗から算定した貫入抵抗と, 静 的コーン貫入試験による貫入抵抗を比較した図であ る. 油圧抵抗から算定した貫入抵抗 (図中プロット) は, 静的コーン貫入試験結果（図中ライン）とほぼ 一致しており，式(11)に示した貫入力推定式の有効 性が伺える.

\section{5. 実現場における貫入抵抗の推定}

貫入力推定式の実現場での適用性・汎用性を検討 するため, PBD 工法を採用している複数の現場に対 して, 式(11)を用いたコーン貫入抵抗の算定を試み た. 表-3は，検討対象とした現場の一覧である. 対 象とする 7 箇所の現場では, 軟弱層の層厚 (PBD 打 設長) や使用寸る PBD 打設機, ケーシング重量が異 なっている. また, 補正係数 $\alpha$ についてはすべての 現場で固定值 1.0 を, 補正係数 $\beta$ については $0.01 〜$ 0.1 の範囲で $\beta$ の值を変化させて貫入抵抗を計算し, コーン貫入試験結果と最も良く一致する表-3 に示 す值を採用した. 補正係数 $\beta$ は, ケーシングと地盤

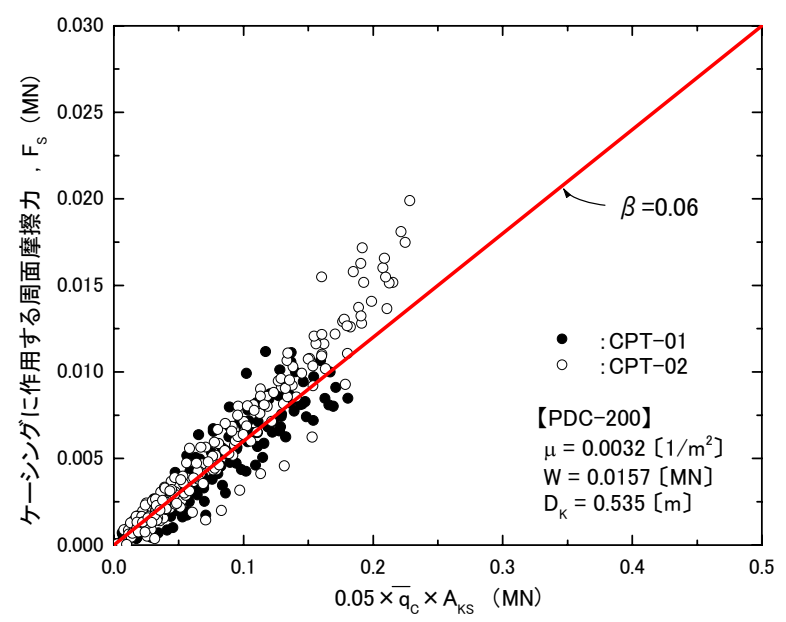

図-12 補正係数 $\beta$ の検討結果
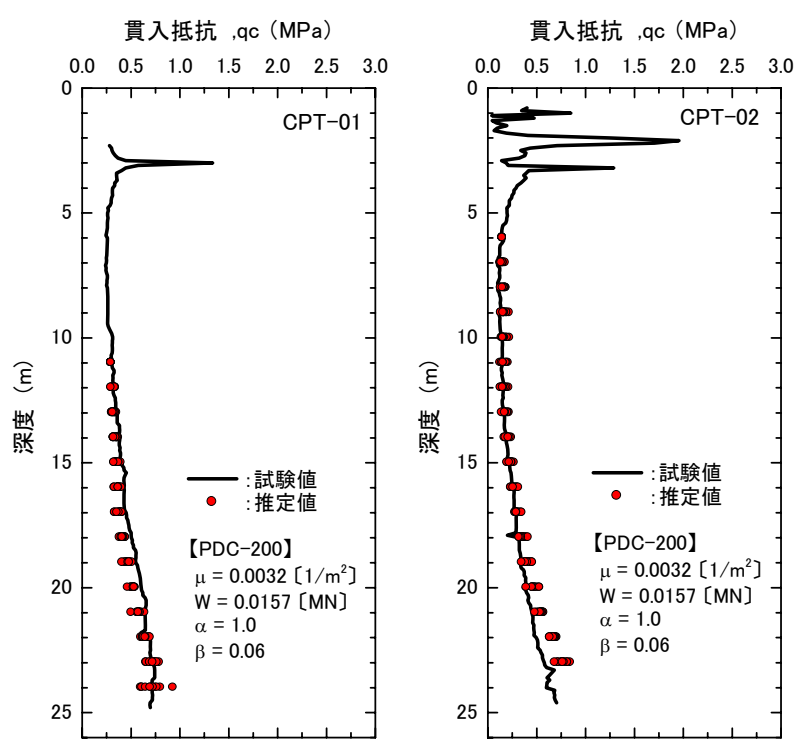

図-13 油圧抵抗から推定した貫入抵抗

表-3 検討対象現場の一覧

\begin{tabular}{|c|c|c|c|c|c|}
\hline & \multicolumn{2}{|c|}{ PBD打設機 } & \multirow{2}{*}{$\begin{array}{c}\text { ケーシング } \\
\text { 重量 } \\
W \quad[\mathrm{MN}\rceil \\
W\end{array}$} & \multicolumn{2}{|c|}{ 補正係数 } \\
\hline & 型番 & $\begin{array}{c}\text { 変換係数 } \\
\mu\end{array}$ & & $\alpha$ & $\beta$ \\
\hline 現場-01 & PCD-300 & 0.0050 & 0.0168 & \multirow{7}{*}{1.0} & 0.06 \\
\hline 現場-02 & PDF-300 & 0.0050 & 0.0141 & & 0.03 \\
\hline 現場-03 & PDF-300 & 0.0050 & 0.0063 & & 0.06 \\
\hline 現場-04 & PDF-200 & 0.0032 & 0.0075 & & 0.03 \\
\hline 現場-05 & PDF-200 & 0.0032 & 0.0088 & & 0.07 \\
\hline 現場-06 & PDC-300 & 0.0050 & 0.0098 & & 0.06 \\
\hline 現場-07 & PCD-300 & 0.0050 & 0.0098 & & 0.05 \\
\hline
\end{tabular}

の摩擦係数の影響, 周辺地盤のリモールドの影響を 考慮した值であり，対象現場の地盤物性に大きく依 存するため, 各現場の地盤状況に合った補正係数 $\beta$ を使用することが必要である.

図-14 は，事前調査として実施した静的コーン貫 入試験位置近傍の油圧抵抗（オシログラフ）と，推 定した貫入抵抗の深度分布である。油圧抵抗から推 定した貫入抵抗は, 式(8)に示すように周面摩擦係数 $F R$ を 0.05 と仮定しているため, 硬い層（砂層）で 

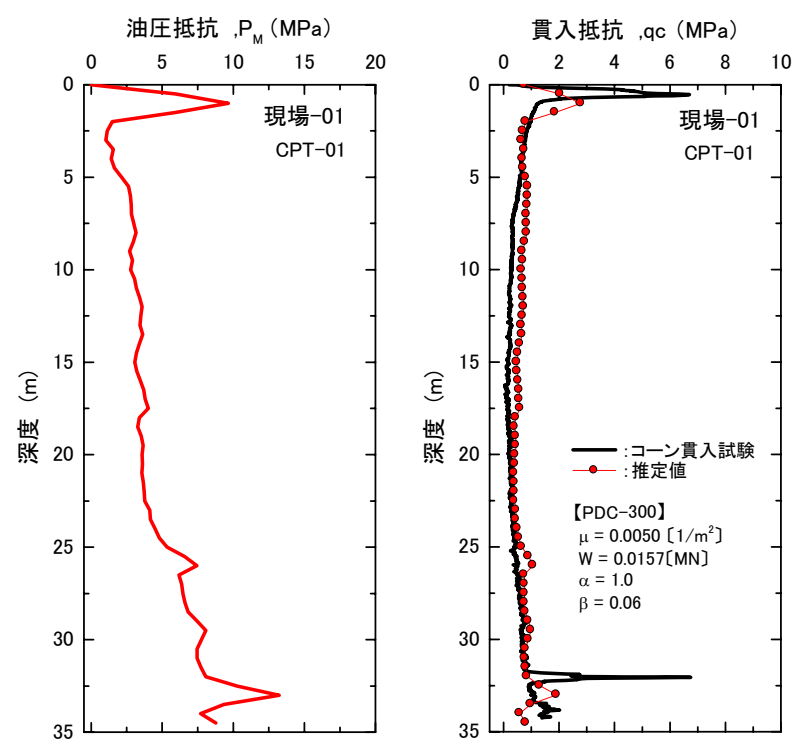

(a) 現場-01（CPT-01 位置）
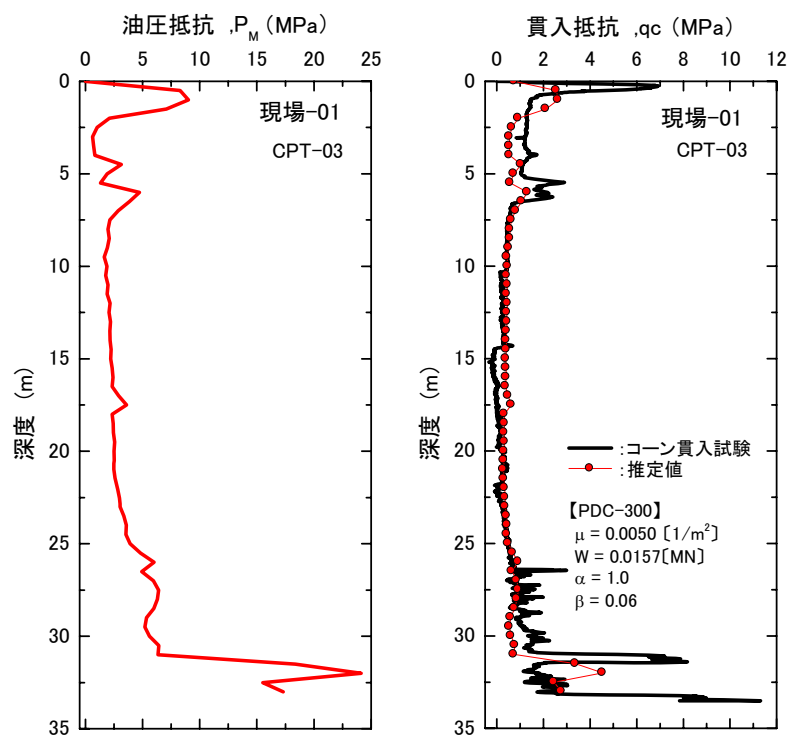

(c) 現場-01（CPT-03 位置）

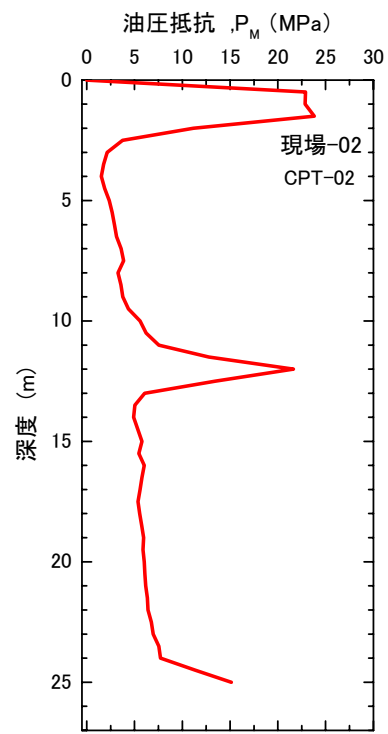

(e) 現場-02（CPT-02 位置）

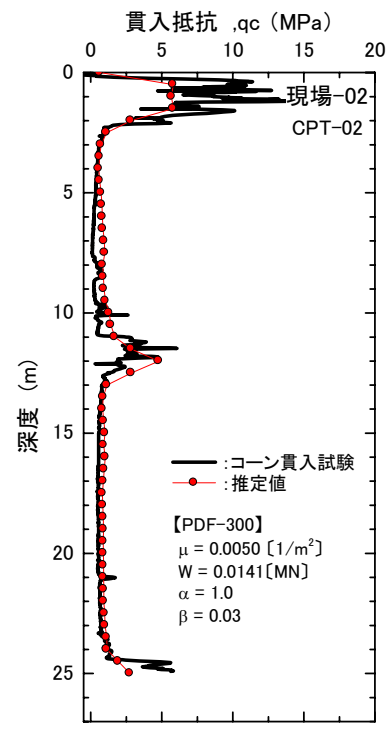

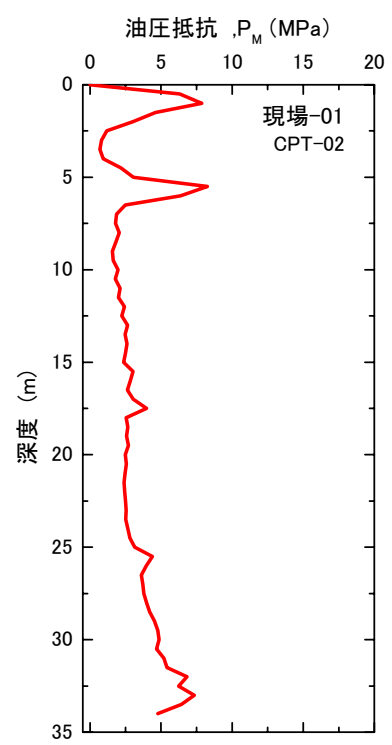

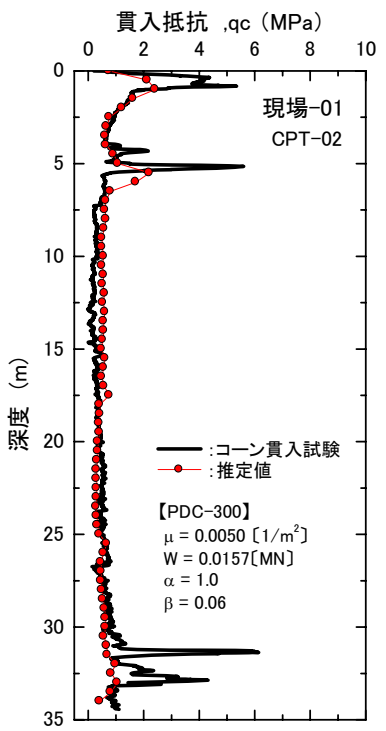

(b) 現場-01（CPT-02 位置）
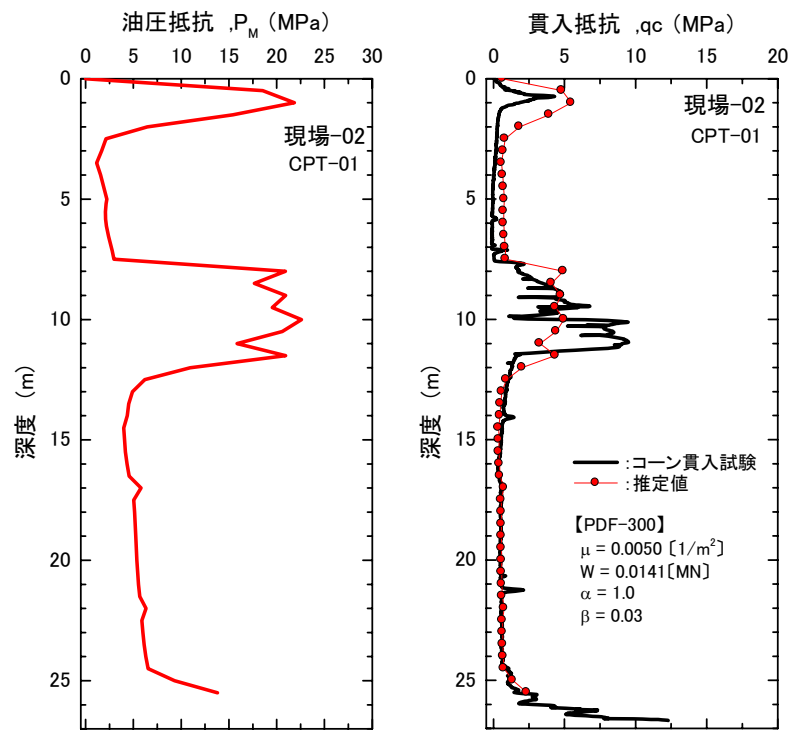

(d) 現場-02（CPT-01 位置）

図-14 静的コーン貫入試験と油圧抵抗から推定した貫入抵抗の比較

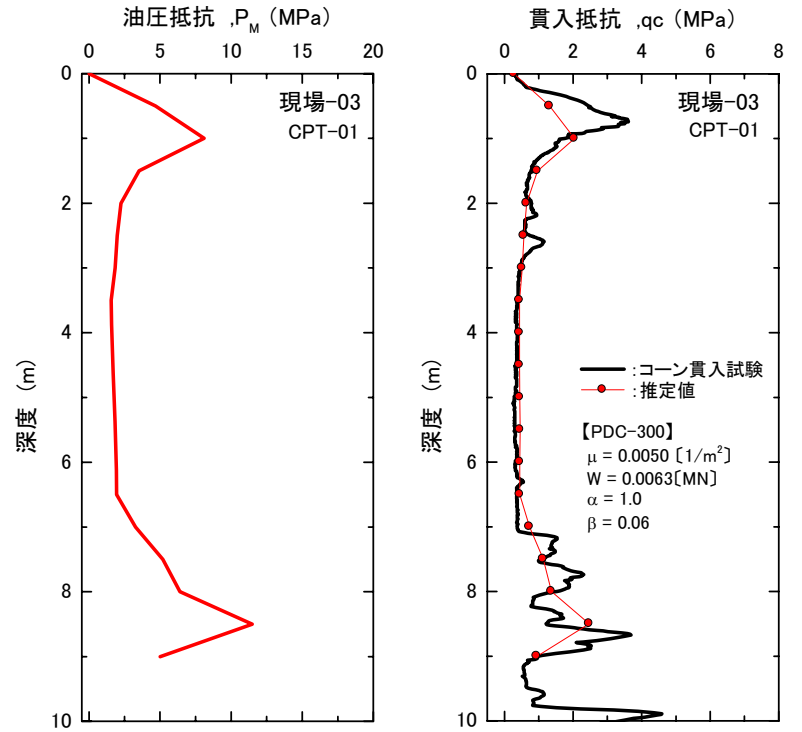

(f) 現場-03（CPT-01 位置） 

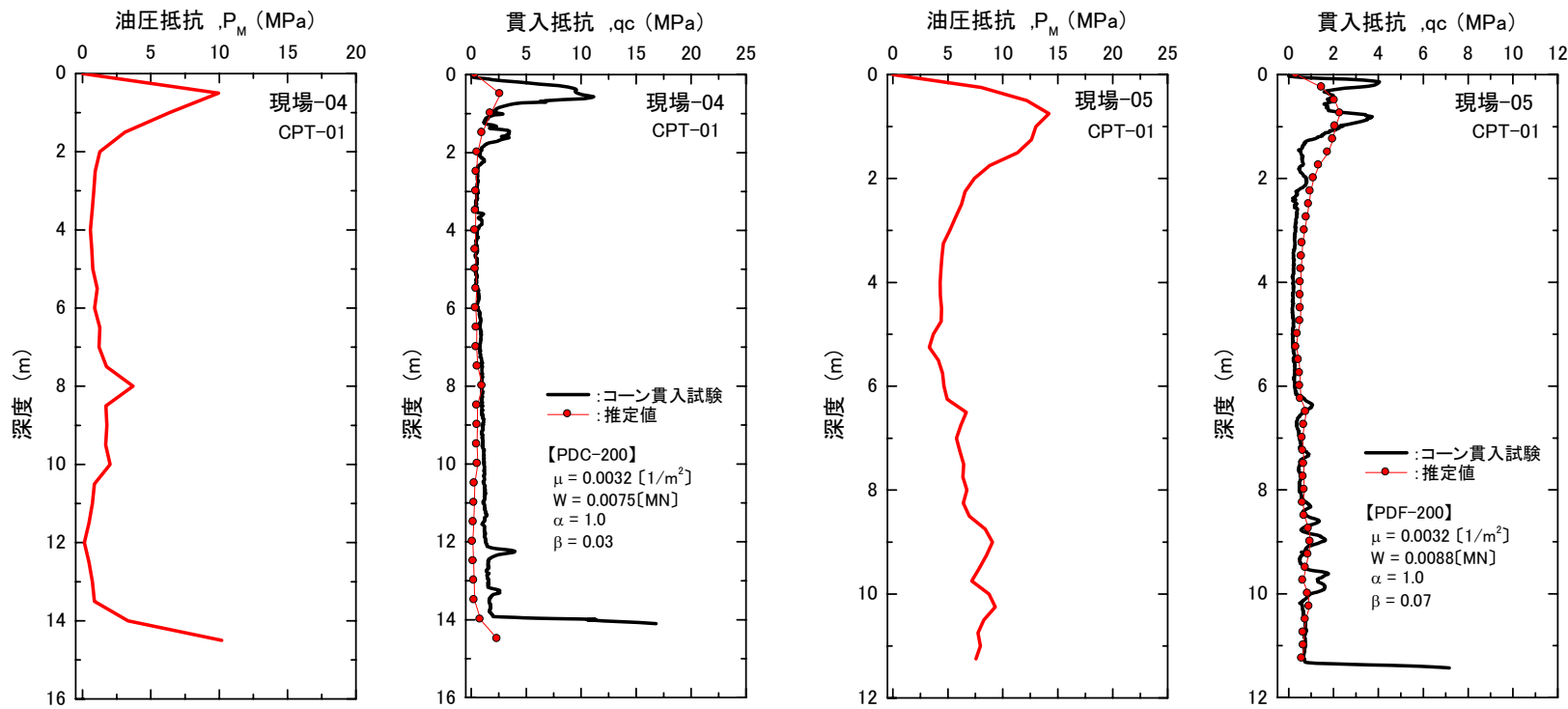

(g) 現場-04（CPT-01 位置）

(h) 現場-05（CPT-01 位置）

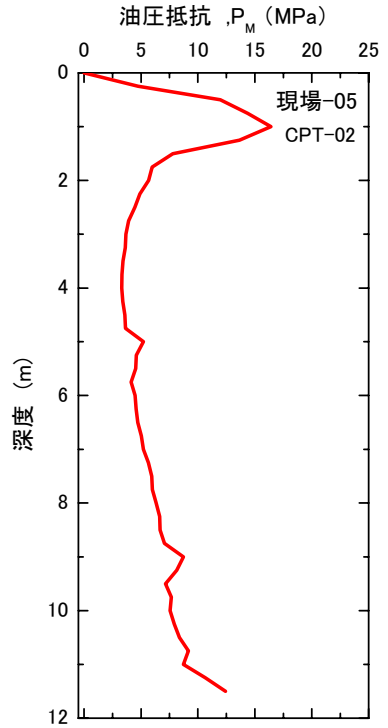

貫入抵抗, $\mathrm{qc}(\mathrm{MPa})$

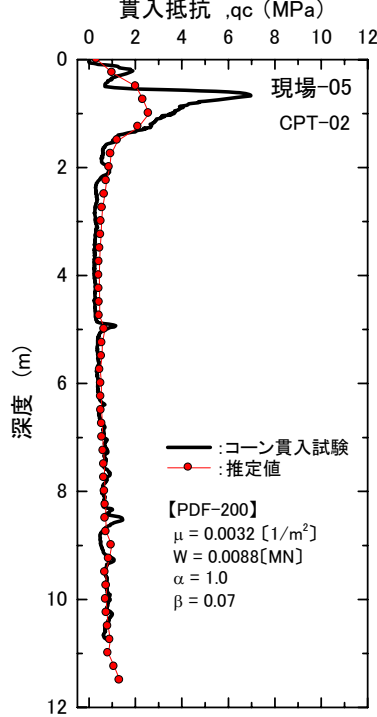

(i) 現場-05（CPT-02 位置）
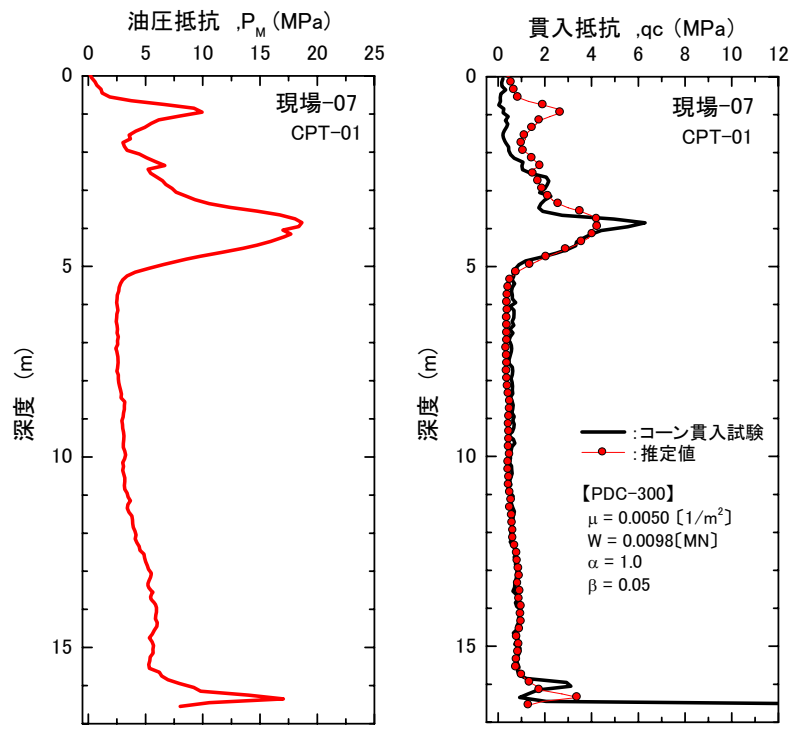

(k) 現場-07（CPT-01 位置）
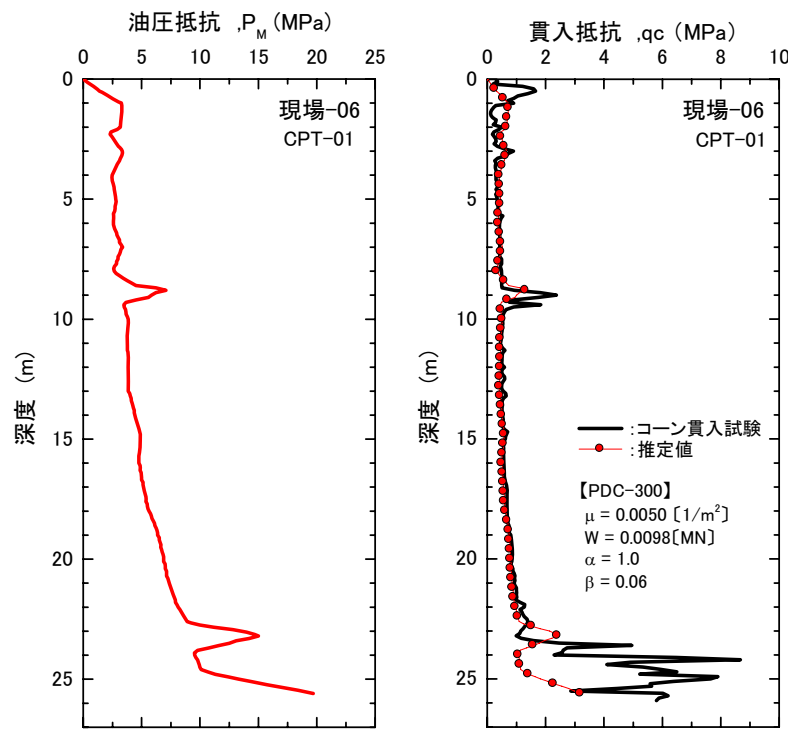

(j) 現場-06（CPT-01 位置）

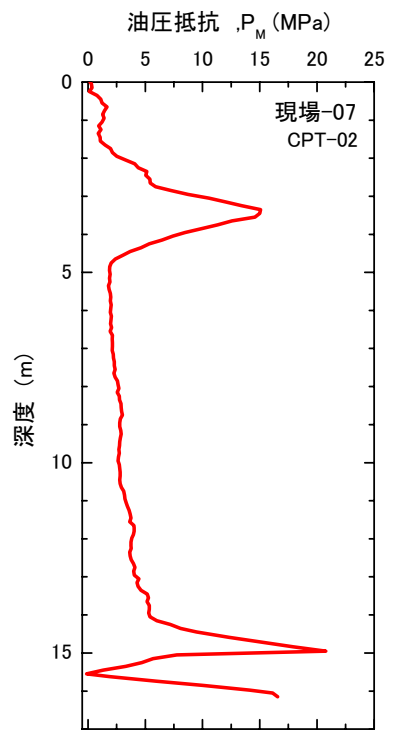

貫入抵抗, $\mathrm{qc}(\mathrm{MPa})$

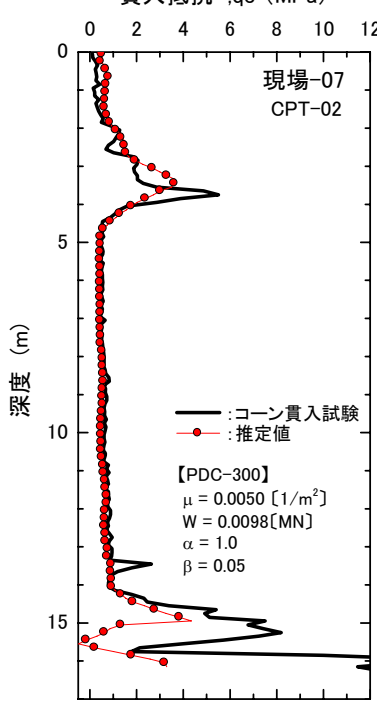

(l) 現場-07（CPT-02 位置）

図-14 静的コーン貫入試験と油圧抵抗から推定した貫入抵抗の比較 

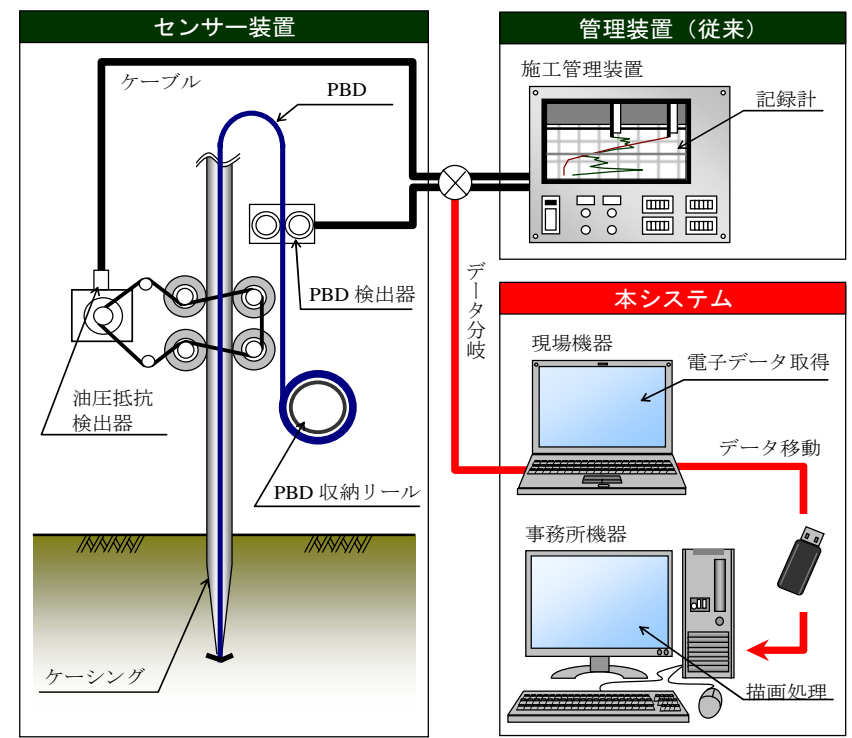

図-15システム概略図（文献 12）に加筆）

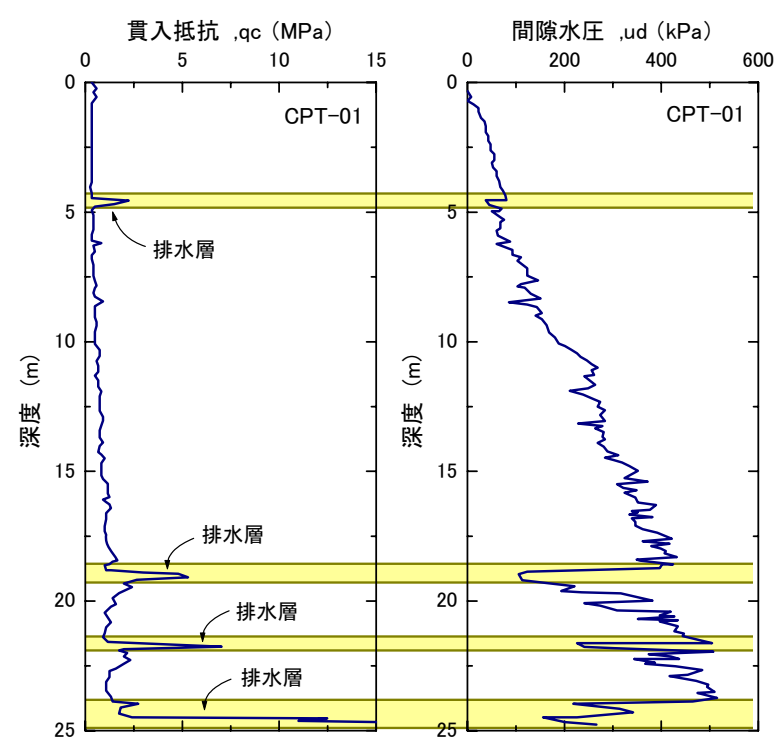

図-16 事前調查による静的コーン貫入試験結果
は若干小さめに評価されるものの, 静的コーン貫入 試験結果とほぼ一致しており, 貫入力推定式の実現 場に対する適用性が確認できる。 なお，図-14 に示 した貫入抵抗から, 補正係数 $\beta$ は硬い層（砂層）が 多く軟弱層が比較的薄い地盤では $0.03 \sim 0.05$ 程度, 硬い層（砂層）が少なく軟弱層が厚い地盤では 0.05 〜0.07 程度の値となる傾向にある. これは, 砂層が 多く含まれる地盤では, 軟弱層との層境に砂分やシ ルト分が多く含まれるため, ケーシングの周面摩擦 に影響を与えることが要因と考えられる。このよう な補正係数 $\beta$ と地盤物性との関係については, 今後 さらにデータ収集・分析を行うことで，傾向を把握 することが可能であると思われる，しかし，PBD工 法を採用する地盤では, PBD の打設長や打設間隔を 設定するために事前調査が実施されるため, この事 前調查結果とのフィッティングにより, 実際の地盤 に合う補正係数 $\beta$ を設定することが望ましい.

\section{6. 地盤強度分布と地質分布の推定}

PBD 工法では，通常 $0.6 \sim 1.5 \mathrm{~m}$ 程度の間隔で多数 の PBD が打設される. このため, 打設位置情報と油 圧抵抗から算定した貫入抵抗を用いて, 地盤内の強 度分布を連続的かつ多次元的に評価することが可能 である、しかしながら，従来のアナログ式管理シス テムでは，油圧抵抗等のデータは記録紙にのみ出力 されるため, 地盤の強度分布をプログラム処理する ことが困難である，そこで，図-15 に示すようにケ ーブルを分岐させ，油圧抵抗等の電子データをパソ コンにて取得し, 提案する推定式を用いて貫入抵抗
を算定, 図化処理するシステムを作成した.

実際の現場において本システムを導入し，その適 用性・有用性を検討した. 図-16 は，今回対象とし た現場において，事前調查として実施した静的コー ン貫入試験(電気式コーン貫入試験)の結果である. 対象地盤は, 圧密対象層（粘性土）と排水層（砂層） の互層となっており, 貫入抵抗には大きな強度差が あることが確認できる. 図-17 は，事前調查結果か ら想定した地質断面図である. PBD 工法は，この地 質想定図を基に, 深度 $25 \mathrm{~m}$ 付近までの軟弱層を対象 として $1.2 \mathrm{~m} \times 1.2 \mathrm{~m}$ の正方配置で設計・施工されて いる．なお，対象地盤は軟弱層の間に排水層が複雑 に堆積していることが予測される。しかしながら， PBD 打設範囲では静的コーン貫入試験がわずか 2 箇 所しか実施されておらず，図-17 が実際の地盤を忠 実に再現した地質想定断面図であるとは言い難く, この図を基に設計したドレーン配置や圧密放置期間 が適切であるかの判断は困難である.

図-18 は，油圧抵抗から推定した貫入抵抗と静的 コーン貫入試験結果（図-17 参照）を比較したグラ フである. PBD を打設する際には, 表層に敷砂が施 工されているため, 敷砂の層厚分だけ深度を補正し 比較している. 油圧抵抗から推定した貫入抵抗は, 砂層部分で実際より小さめに推定されているものの, 静的コーン貫入試験結果とほぼ一致しており，提案 した推定式の精度は十分であると考えられる。油圧 抵抗から推定した貫入抵抗（約 7000 本分）と打設位 置情報から，改良範囲の貫入抵抗分布を図化処理し たものが図-19 である.PBD の打設間隔が非常に密 であるため, 地盤の強度分布を連続的かつ多次元的 に把握できることがわかる. 図-20 は, 図-19 に示し 


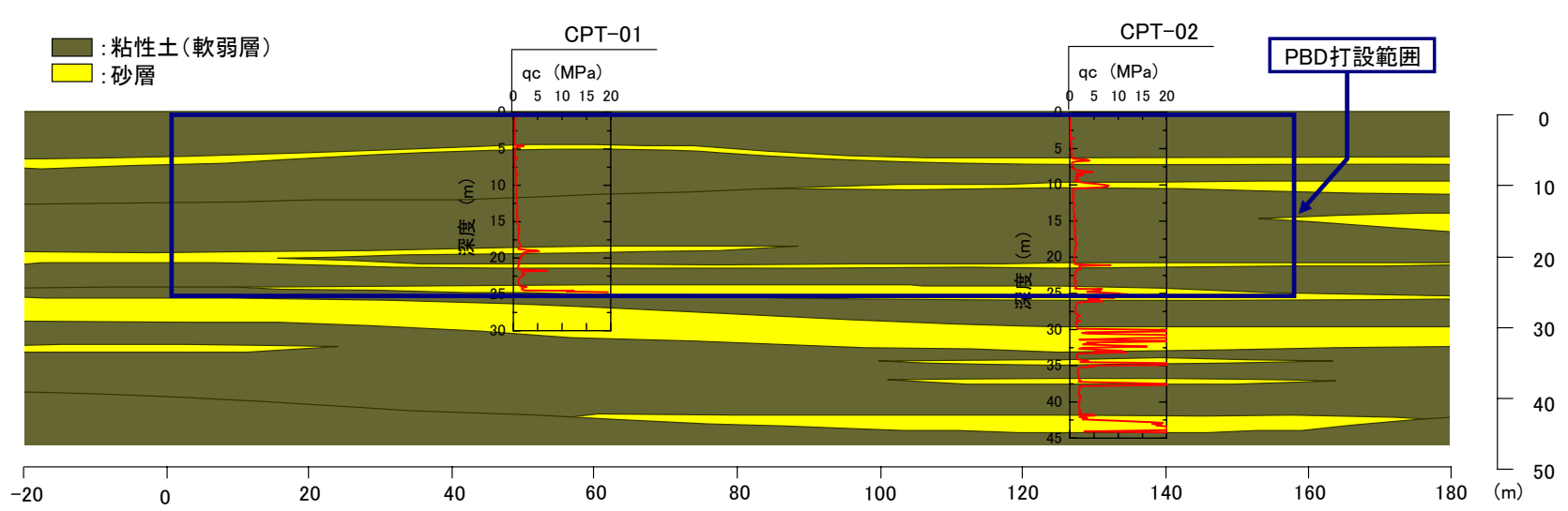

図-17 事前調査から想定した地質断面図と PBD 打設範囲

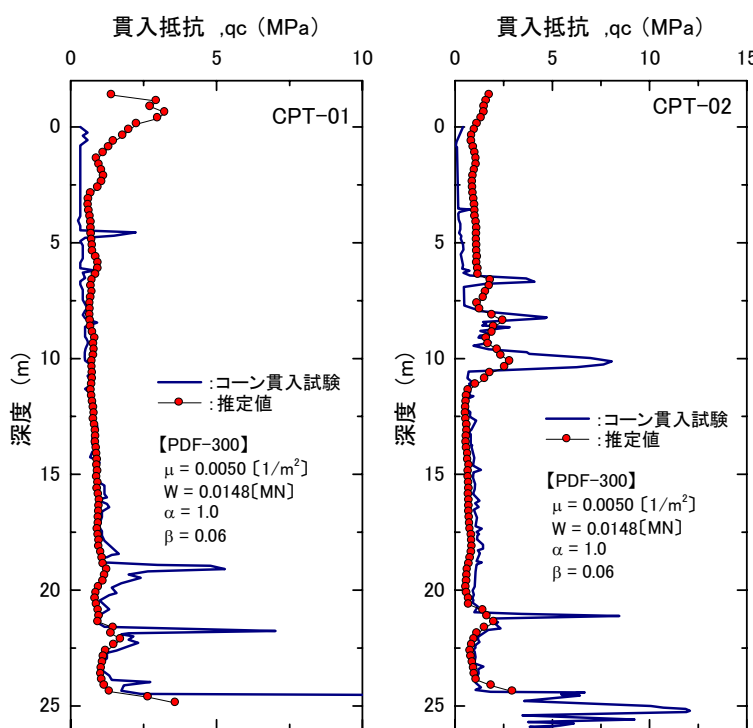

図-18 推定した貫入抵抗とコーン貫入試験の比較

た任意断面に対して，貫入抵抗分布を切り出した図 である。これらの分布図から, 地盤強度の高い排水 層（砂層）と思われる層が，軟弱地盤内に傾斜して 堆積している様子がわかる. なお，これらの分布図 において貫入抵抗が大きい表層部分は, 敷砂施工に よる影響である。

今回対象とした現場では，圧密対象層（粘性土） と排水層（砂層）の貫入抵抗には大きな差があるた め (図-16参照), 地盤強度加ら圧密対象層と排水層 の区別が可能である. 図-21 は, 図-20に示した各断 面の貫入抵抗分布を, $q_{C}=1.5 \mathrm{MPa}$ を境界として軟ら かい層（粘性土） と硬い層（砂層）の 2 色に塗り分 けた図である. 図-21 の A-A'断面は, 図-17 に示し た地質断面図位置における地質推定断面図であるが, 図-17 と比較すると砂層分布位置にあまり大きな違 いは見られないことがわかる。しかしながら，A-A 断面では深度 $10 \mathrm{~m}$ 付近の砂層が断面左側にも分布 していること, 断面右側の深度 5〜15m 付近の砂層 が想定よりも厚く堆積していることから, 圧密速度

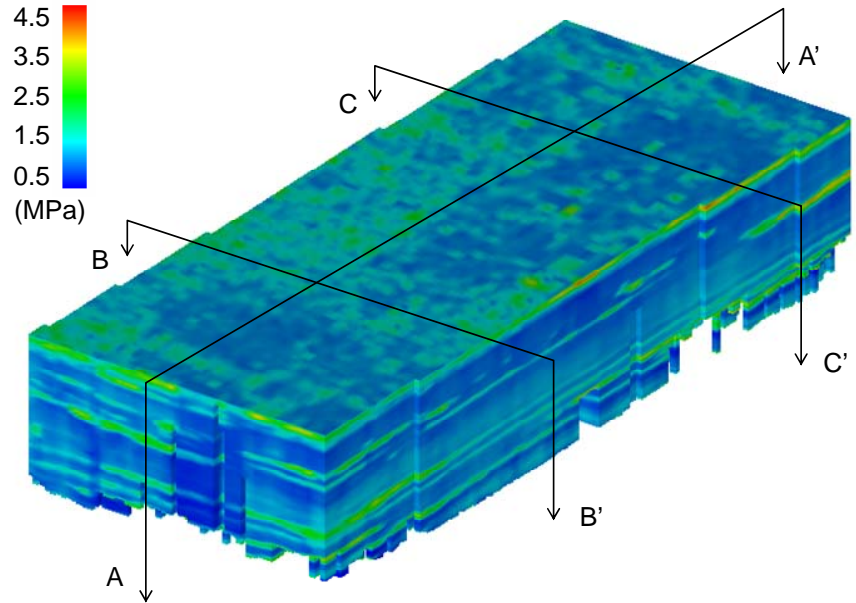

図-19 推定した貫入抵抗の分布（3 次元）

や沈下量が設計值とは異なることが予想されるとと もに, PBD 打設範囲内での不等沈下も懸念される.

以上のように, 油圧抵抗と打設位置情報から推定 した強度分布や地質分布結果は，実際の地盤を精度 良く表現できているものと考えられる，なお，本手 法によって推定される強度分布や地質分布は, PBD 打設中あるいは打設後に得られるものである。この ため, 設計段階で実施する事前調査とは性質が異な り，PBDがどのような地盤に施工され，その効果は どの程度となるかを管理する, いわゆる品質管理に 用いられるものとなる. 本システムにより得られる 強度分布や地質分布は, 沈下計算や安定計算, FEM 変形解析 ${ }^{13)}$, 14) 等へ利用寸ることで, PBD 打設後の 盛土施工速度や施工手順の検討，不等沈下や残留沈 下の予測が精度良く実施可能であり, 工期短縮や工 程管理, PBD 工法の性能評価等に有用であると思わ れる. なお, PBD 打設機の油圧抵抗は, 従来から施 工管理の一環としてオシログラフに記録されるもの であり, 本システムを導入するために, PBD 打設機 

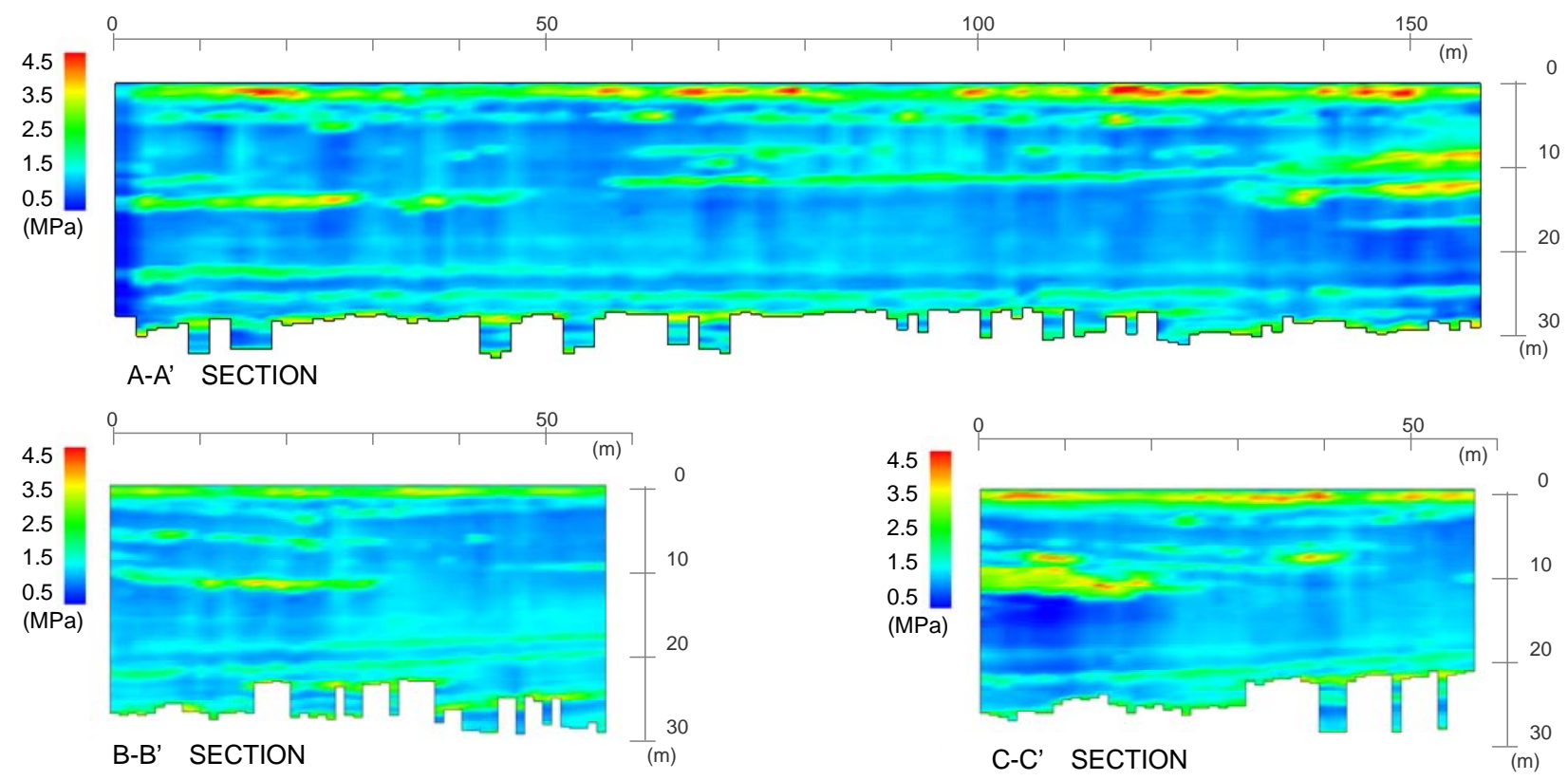

図-20 推定した貫入抵抗の分布（2 次元）

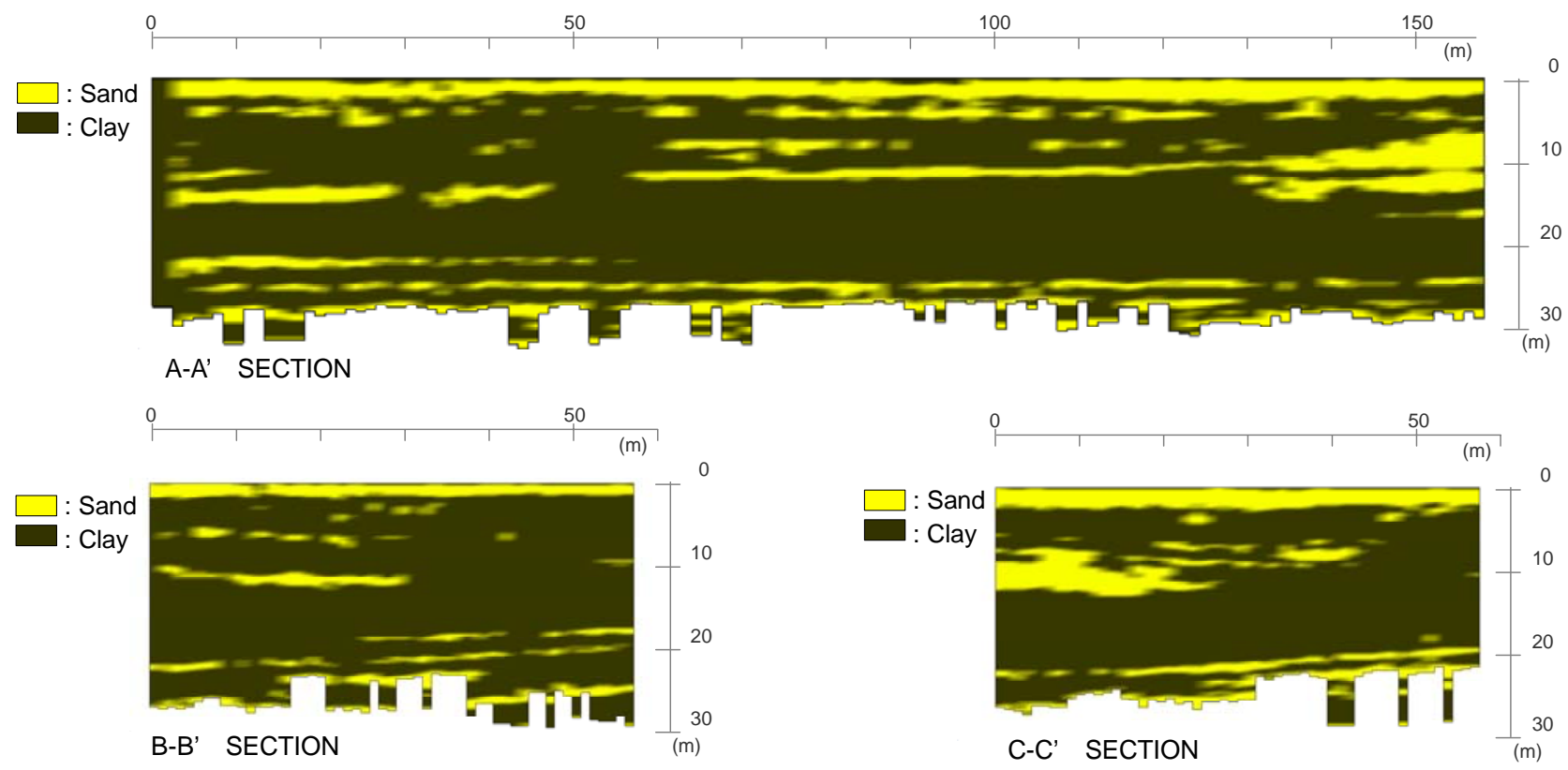

図-21 貫入抵抗分布から推定した地質断面図

の大幅な改良や新たな計測器設置等は必要ない。こ のため, 通常の地盤調査等に比べ，非常に簡易かつ 安価に導入可能であることも，本システムの大きな 特徵の 1 つである.

\section{7. おわりに}

本論文では，PBD 打設時に計測した油圧抵抗から， 静的コーン貫入試験における貫入抵抗を算定する簡 易な推定式を提案した。この推定式に対して, PBD 打設機を用いた試験結果や，実際の現場に対して適
用した結果から，精度良く地盤強度（貫入抵抗）を 推定可能であることが確認できた。 また，この推定 式から算出した地盤強度と打設位置情報を用いて, PBD 打設地盤の強度分布や地質分布を，連続的かつ 多次元的に評価するシステムを作成し，実際の現場 に導入することでその適用性・有用性について検討 を行った．推定した強度分布や地質分布は，実際の 地盤を精度良く表現できており，沈下・安定計算や FEM 変形解析等へ利用することで, 工期短縮や工程 管理, PBD 工法の性能評価等に有効活用できると考 えられる。

なお，本論文で提案した貫入力推定式は，粘性土 
を対象としているため, 砂層における貫入抵抗を小 さく評価する傾向にある. 油圧抵抗から推定した貫 入抵抗を安定解析等に直接使用寸るためには, 砂層 の貫入抵抗に対する補正方法を検討し, 推定值の精 度を向上させることが今後の課題として挙げられる. また，今後はこの手法を広く実現場に適用し，さら なるデータの収集・分析を行う予定である.

謝辞 : 本論文を作成するにあたり，ご協力いただい た関係者各位および中日本高速道路の山田耕一氏, 川井田実氏に深く感謝いたします。

\section{参考文献}

1) プラスチックボードドレーン協会 : プラスチックボ ードドレーン工法 その理論と実際, 鹿島出版会, pp.99-130, 2009.

2) 渡部要一, 鈴木和実, 新舎博, 宮本健児 : PBD 打設時 のマンドレル貫入抵抗による土質判定, 土木学会第 64 回年次学術講演会講演概要集, III-181, pp.361-362, 2009.

3) 久保大輔, 平田昌史, 中山泰起, 福田淳, 山田耕一, 川井田実：オシログラフを利用した軟弱地盤におけ る砂層位置の推定, 土木学会第 65 回年次学術講演会 講演概要集, III -393, pp.785-786, 2010.

4) 室町忠彦：静的コーンペネトロメータの軟弱地盤調 查への適用に関する実験的研究, 鉄道技術報告, No.757(施工編第 333 号), 1971.

5) Muromachi, T. : Cone penetration testing in Japan, Proc. of Cone Penetration testing and experience, ASCE National Conv., St. Louis, pp.49-75, 1981.

6) 土質調查法改定委員会編 : 地盤調查法, 地盤工学会, pp.233-235, 1995.

7) 室町忠彦, 赤木俊允 共訳 : 貫入試験と地盤調查, 鹿 島出版社, pp.183-210, 1976.

8) Begemann, H.K.S.Ph. : The Friction Jacet Cone as an Aid in Determining the Soil Profile, Proc. of the $6^{\text {th }}$ ICSMFE, Vol.I, pp.17-20, 1965.

9) Schmertmann, J.H. : Dutch friction-cone penetrometer exploration of research area atfield 5, Eglin Air Force Base, Florida, U.S. Army Eng. Waterways Exp. Stat., Vicksburg, Miss., Contact Rep., S-69-4, 1969.

10) Robertson, P.K. : Soil classification using the cone penetration test, Canadian Geotechnical Journal, Vol.27, No.1, pp.151-158, 1990.

11) Meyerhof, G.G. : Penetration Test and Bearing Capacity of Cohesionless Soils, Proc. of the ASCE, Journal of the Soil Mech. and Found. Div., Vol.82, No. SM1, p.866, 1956.

12) NCB ドレーン協会 : 設計施工マニュアル, p.61, 2001.

13）鈴木哲太郎, 平田昌史, 福田淳, 水野智幸, 山田耕一, 川井田実：超軟弱地盤における載荷盛土の FEM 解 析, 土木学会第 65 回年次学術講演会講演概要集, III -389, pp.777-778, 2010.

14) 西川浩二, 平田昌史, 福田淳, 信田潤一, 山田耕一, 川井田実：軟弱地盤における載荷盛土を伴う真空圧 密工法の FEM 解析〜その 1, 土木学会第 65 回年次学 術講演会講演概要集, III -234, pp.467-468, 2010.

(2010.11. 30 受付)

\title{
DEVELOPMENT OF GEOLOGICAL DISTRIBUTION PRESUMPTION METHOD USING OIL PRESSURE RESISTANCE OF THE PLASTIC BOARD DRAIN MACHINE
}

\author{
Masafumi HIRATA, Shinichiro SHIRAGA, Hideki SHIMIZU, Jun FUKUDA, \\ Shuu KAWANABE and Tadaaki NOMURA
}

Plastic board drain (PBD) method is a consolidation method which can accelerate consolidation by placing a lot of PBD into the soft ground. It is important for PBD method to get information about the layer thickness of soft ground and geological distribution, before designing the optimal arrangement of PBD. However, it is difficult to get the accurate information by soil exploration with an only few samples.

In this paper, the simplified estimating equation is proposed that evaluates cone bearing capacity by using oil pressure resistance of placing PBD machine during operating. Furthermore, the system is proposed that can evaluate the distribution in three dimensions of ground strength by using estimated cone bearing capacity. Finally, it was confirmed that this proposed system could evaluate the layer thickness of soft ground and geological distribution accurately. 